\title{
Sorption and Transport of Iodine Species in Sediments from the Savannah River and
} Hanford Sites

Qinhong Hu, ${ }^{1, *}$ Pihong Zhao, ${ }^{1}$ Jean E. Moran, ${ }^{1}$ and John C. Seaman ${ }^{2}$

\author{
${ }^{1}$ Chemistry and Materials Science Directorate \\ Lawrence Livermore National Laboratory \\ 7000 East Avenue, MS L-231 \\ Livermore, CA 94550 \\ ${ }^{2}$ Advanced Analytical Center for Environmental Sciences \\ Savannah River Ecology Laboratory \\ University of Georgia
}

Aiken, SC 29802

Prepared for

Journal of Contaminant Hydrology

June 1, 2004

*Corresponding author (phone: 925-422-6774; fax: 925-422-3160; e-mail: hu7@1lnl.gov)

Approved for public release; further dissemination unlimited 


\section{DISCLAIMER}

This document was prepared as an account of work sponsored by an agency of the United States Government. Neither the United States Government nor the University of California nor any of their employees, makes any warranty, express or implied, or assumes any legal liability or responsibility for the accuracy, completeness, or usefulness of any information, apparatus, product, or process disclosed, or represents that its use would not infringe privately owned rights. Reference herein to any specific commercial product, process, or service by trade name, trademark, manufacturer, or otherwise, does not necessarily constitute or imply its endorsement, recommendation, or favoring by the United States Government or the University of California. The views and opinions of authors expressed herein do not necessarily state or reflect those of the United States Government or the University of California, and shall not be used for advertising or product endorsement purposes.

This work was performed under the auspices of the U. S. Department of Energy by the University of California, Lawrence Livermore National Laboratory under Contract No. W7405-Eng-48.

This report has been reproduced directly from the best available copy.

Available to DOE and DOE contractors from the

Office of Scientific and Technical Information

P.O. Box 62, Oak Ridge, TN 37831

Prices available from (423) 576-8401

http://apollo.osti.gov/bridge/

Available to the public from the

National Technical Information Service

U.S. Department of Commerce

5285 Port Royal Rd., Springfield, VA 22161

http://www.ntis.gov/

OR

Lawrence Livermore National Laboratory

Technical Information Department's Digital Library

http://www.llnl.gov/tid/Library.html 


\section{Abstract}

Iodine is an important element in studies of environmental protection and human health,

3 global-scale hydrologic processes and nuclear nonproliferation. Biogeochemical cycling of

4 iodine is complex, because iodine occurs in multiple oxidation states and as inorganic and

5 organic species that may be hydrophilic, atmophilic, and biophilic. In this study, we focused on

6 the sorption and transport behavior of iodine species (iodide, iodate, and 4-iodoaniline) in

7 sediments collected at the Savannah River and Hanford Sites, where anthropogenic ${ }^{129}$ I from

8 prior nuclear fuel processing activities poses an environmental risk. We conducted both column

9 and batch experiments to investigate the sorption and transport behavior of iodine, and the

10 sediments we examined exhibit a wide range in organic matter, clay mineralogy, soil $\mathrm{pH}$, and

11 texture.

12 The results of our experiments illustrate complex behavior with various processes

13 occurring, including iodate reduction, irreversible retention or mass loss of iodide, and rate-

14 limited and nonlinear sorption. There was an appreciable iodate reduction to iodide, presumably

15 mediated by the structural Fe(II) in some clay minerals; therefore, careful attention must be

16 given to potential interconversion among species when interpreting the biogeochemical behavior

17 of iodine in the environment. The different iodine species exhibited dramatically different

18 sorption and transport behavior in three sediment samples collected from different depths at the

19 Savannah River Site. This indicates that, when anthropogenic ${ }^{129} \mathrm{I}$ is deposited on the surface at

20 this site, the different iodine species will have different residence times as they migrate through

21 the various sediment regimes. Our study results yielded additional insight into processes and

22 mechanisms affecting the geochemical cycling of iodine in the environment, and provided

23 quantitative estimates of key parameters (e.g., extent and rate of sorption) for risk assessment at

24 these sites. 
1 Key Words: iodine, sorption, transport, sediment.

\section{1. Introduction}

Iodine is an essential micronutrient in animals and humans, necessary for the production of thyroid hormones and for the proper functioning of the thyroid gland, and deficiencies can lead to severe metabolic disorders. As reported by the World Health Organization in 1999,

7 iodine deficiency is a significant public health problem in 130 countries, with one-third of the

8 world's population estimated to be at risk. Furthermore, because radioactive iodine is

9 concentrated in the human thyroid (e.g., VanMiddlesworth et al. 2000), an uncontrolled release

10 of radioactive iodine could constitute a direct threat to human populations.

Iodine has one stable isotope, ${ }^{127} \mathrm{I}$, and 25 radioactive isotopes that include 10 fission

12 products with very short half-lives ranging from minutes to a few hours. Two radionuclides $\left({ }^{131} \mathrm{I}\right.$

13 and ${ }^{129} \mathrm{I}$ ) are particularly of environmental concern. Following a nuclear accident (such as the

14 one at Chernobyl) or an intentional radiological release, ${ }^{131}$ I would be an acute contaminant

15 because of its short half-life of 8.05 days and a high specific activity.. Having a relatively long

16 half-life $\left(1.57 \times 10^{7}\right.$ years $),{ }^{129} \mathrm{I}$ is an important fission product with a fission yield of $0.9 \%$ from

17 uranium-235 and 1.6\% from plutonium-239. Nuclear-fuel reprocessing facilities constitute the

18 major source of ${ }^{129}$ I released in the environment. Up until 1998, a total of 2,300 $\mathrm{kg}$ of ${ }^{129} \mathrm{I}$ was

19 discharged in the marine environment by two European facilities at La Hague in France and

20 Sellafield in England, an amount that is 50 times the total release from nuclear weapon tests

21 (Hou et al. 2001; Fréchou and Calmet 2003). From 1944 through 1972, the plutonium-

22 production operation at the Hanford Site in Washington released about $260 \mathrm{~kg}$ of ${ }^{129} \mathrm{I}$ into the air.

23 In comparison, the operation of production reactors from 1953 to about 1990 at the Savannah

24 River Site (SRS) in South Carolina released about $32 \mathrm{~kg}$ of ${ }^{129} \mathrm{I}$ into the air. 
${ }^{129} \mathrm{I}$ is the only long-lived, naturally-occurring radioactive isotope of iodine. It is

2 produced by cosmic-ray interactions with xenon in the upper atmosphere and by spontaneous

3 fission of uranium-238 in the geosphere. Anthropogenic inputs of ${ }^{129}$ I have overwhelmed the

4 natural inventory, increasing the hydrospheric ${ }^{129} \mathrm{I} /{ }^{127} \mathrm{I}$ ratio from $1.5 \times 10^{-12}$ during the

5 prenuclear era up to $10^{-10}-10^{-4}$ (Moran et al. 1998; Fréchou et al. 2003; Kekli et al. 2003). This

6 change in the ratio creates an opportunity for the application of anthropogenic ${ }^{129} \mathrm{I}$ as an

7 environmental tracer, originally proposed by Edwards (1962), to examine a variety of processes

8 including ocean circulation, biogeochemical cycling, and regional hydrologic (e.g., atmosphere,

9 surface water, and groundwater) processes (e.g., Moran et al. 1999; Oktay et al. 2001).

10 Iodine exhibits complex geochemical behavior. With oxidation states ranging from -1 to

$11+7$, the predominant states in aqueous systems are -1 (iodide, $\mathrm{I}^{-}$) and +5 (iodate, $\mathrm{IO}_{3}{ }^{-}$). The

12 iodine species exhibit unique hydrophilic, atmophilic, and biophilic characteristics (Fuge and

13 Johnson 1986). The fate and transport of iodine in aqueous environments is dictated by its

14 chemical speciation. In reducing environments, aqueous iodine usually occurs as the mobile

15 monovalent anion, $\mathrm{I}^{-}$. Under more oxidizing conditions, iodine is present as the more reactive

$16 \mathrm{IO}_{3}{ }^{-}$, which can lead to retarded transport through interaction with clays and organic matter.

17 Coexistence of various inorganic and organic iodine species, in different proportions, has

18 been reported in various environments (Liss et al. 1973; Wolfsberg 1978; Couture and Seitz

19 1983; Yuita 1992, 1994; Yamada et al. 1999; Muramatsu and Ohmono 1988; Baker et al. 2001).

20 However, there are conflicting reports regarding the extent of sorption for $\mathrm{I}^{-}$and $\mathrm{IO}_{3}^{-}$. While $\mathrm{I}^{-}$is

21 often considered to undergo limited sorption, and is in fact employed as a nonreactive tracer

22 (Fuhrmann et al. 2000; Turin et al. 2002), an increasing body of evidence indicates appreciable

23 sorption of $\mathrm{I}^{-}$in a variety of geologic media (Sheppard et al. 1996; Yoshida et al. 1998; Kaplan 
1 2003). Interconversion of iodine species may, to some extent, contribute to the conflicting

2 results. In addition, few publications address the fate and transport of organic iodine compounds.

4 species (i.e., iodide, iodate, and 4-iodoaniline), particularly the extent and rate of interaction of

5 these iodine species with geologic media from two nuclear facilities in the U.S. Department of

6 Energy (DOE) complex, where release of radionuclides including ${ }^{129}$ I has occurred (NRC 2000).

7 We also investigated the conversion of iodate to iodide and the associated implications. Such

8 knowledge is critical for a defensible environmental safety assessment of nuclear waste disposal.

9 Our work also contributes to the application of ${ }^{129} \mathrm{I}$ as an intrinsic tracer to examine

10 biogeochemical cycling and to the detection of possible illicit proliferation of nuclear materials.

\section{$11 \quad$ 2. Materials and Methods}

$12 \quad 2.1$ Materials

13 We obtained four uncontaminated sediments from SRS in South Carolina and the

14 Hanford Site in Washington for laboratory tests (Table 1). These locations represent a vast

15 contrast in geologic and climatologic variability (NRC 2000). SRS has a humid subtropical

16 climate with annual rainfall of 91-112 cm, and geology representative of Atlantic Coastal Plain.

17 In contrast, the Hanford Site is located in an arid region with an average annual rainfall of only

$18 \quad 16 \mathrm{~cm}$ and a stratigraphy consisting of bedded alluvial plain sediments with sands and gravels.

19 Three SRS sediment samples were collected at different depths, providing an opportunity to

20 examine sorption and transport of iodine species in a vertical sediment core. The wide range in

21 sample types provided us with an opportunity to examine the influence of organic matter, clay

22 mineralogy, soil $\mathrm{pH}$, and texture on the transport behavior of iodine species. All sample

23 properties were measured according to standard procedures (Klute 1986; Sparks 1996) and are

24 presented in Table 1. 
In addition to the above samples, clay minerals including kaolinite from Edgar, FL, illite

2 from Rochester, NY, vermiculite from Sanford, NC, and montmorillonite from Panther Creek,

3 CO were purchased from Ward's Natural Sciences in Rochester, NY. The only pretreatment we

4 performed was to crush these minerals using a mortar and pestle so that they could pass through

5 a $63 \mu \mathrm{m}$ sieve. Iodine chemicals (including $\mathrm{KI}, \mathrm{KIO}_{3}$ and 4-iodoaniline; all with purity $>99 \%$ )

6 were purchased from Aldrich Chemical Co. in Milwaukee, WI. The 4-iodoaniline (chemical

7 formula $\mathrm{IC}_{8} \mathrm{H}_{4} \mathrm{NH}_{2}$ ) was used as a representative refractory organic iodine species. All iodine

8 solutions were prepared using 18 -M $\Omega$ deionized water from a NANOpure Infinity Water

9 Purification System from Barnstead International, Dubuque, IA, and stored in amber glass

10 bottles.

12 2.2 Column and Batch Tests

13 Glass columns - either from Kontes in Vineland, NJ (2.5-cm inner diameter, 15.0-cm) or

14 Omnifit in Boonton, NJ (1.5-cm inner diameter, 10.0-cm long)—were incrementally packed with

15 the air-dried sediment $(<2 \mathrm{~mm})$ to obtain a uniform bulk density. The packed columns were

16 slowly wetted from the bottom with an electrolyte solution (of different concentrations of $\mathrm{CaCl}_{2}$,

17 depending on the test purpose) to establish saturation, with approximately 100 pore volumes of

18 electrolyte solution pumped through the column prior to the transport study.

19 The methods employed for the miscible displacement studies were similar to those used

20 in previous experiments (e.g., Hu and Brusseau 1998). We connected an HPLC pump (Model

21301 from Alltech Associates Inc., Deerfield, IL) to the column, and placed a three-way valve in-

22 line to facilitate switching between treatment solutions. Both iodide and iodate (with an initial

23 concentration of either $1 \times 10^{-5}$ or $1 \times 10^{-4} \mathrm{M}$ ) were simultaneously injected into the column to 
1 study their transport behavior. In some sediments (e.g., the SRS surface sample), a single iodine

2 species was also examined to investigate the potential reduction of $\mathrm{IO}_{3}{ }^{-}$to $\mathrm{I}^{-}$.

3 We also studied the transport of tritium (activity $30 \mathrm{kBq} / \mathrm{L}$ ) so that we could compare the

4 transport behavior of tritium and iodine species in the column studies. Column effluents were

5 collected with an automated fraction collector (Retriever 500, ISCO Inc., Lincoln, NE) for

6 chemical analysis as described below. For 4-iodoaniline transport experiments, the solution was

7 allowed contact only with glass or stainless steel to avoid potential interaction of organoiodine

8 with plastics in the column system. When borosilicate glass tubes were used, we did not observe

9 any mass loss of this organoiodine; however, we did observe a 20\% loss of 4-iodoaniline (tested

10 for a concentration of $10^{-4} \mathrm{M}$ for 7 days) when polypropylene tubes were used.

11 Supplementary batch tests, in accordance with the ASTM method D4646-87 (1998), were

12 conducted to investigate conversion of $\mathrm{IO}_{3}{ }^{-}$and $\mathrm{I}^{-}$in contact with sediment or clay minerals. A

13 solution to solid ratio of 4:1 was employed instead of the 20:1 ratio specified in the ASTM

14 method. (This was done because a ratio of 20:1 is unrealistically high when compared to that

15 commonly encountered under field conditions). We conducted duplicate blank treatments

16 (adding only $\left.10^{-5} \mathrm{M} \mathrm{Cl}^{-}\right)$and triplicate treatments of either iodide $\left(10^{-5} \mathrm{M} \mathrm{I}^{-}\right.$and $\left.10^{-5} \mathrm{M} \mathrm{Cl}^{-}\right)$or

17 iodate $\left(10^{-5} \mathrm{M} \mathrm{IO}_{3}^{-}\right.$and $\left.10^{-5} \mathrm{M} \mathrm{Cl}^{-}\right)$for each sediment or clay mineral. We also prepared control

18 samples in the same manner with $\mathrm{I}^{-}$or $\mathrm{IO}_{3}{ }^{-}$solution but no solid sample material. These

19 treatments were carried out to discern the potential reduction of $\mathrm{IO}_{3}^{-}$to $\mathrm{I}^{-}$.

2.3 Analyses of Iodine Species

We used a Dionex Corp. (Sunnyvale, CA) ion chromatography (IC) DX-600 system to

22 analyze $\mathrm{I}^{-}$and $\mathrm{IO}_{3}^{-}$, as well as other common anions, using a hydroxide gradient method

23 developed by Hu and Moran (2004). The system includes a GP50 gradient pump, an ED50A

24 electrochemical detector in conductivity mode, and an AS50 autosampler with a thermal 
1 compartment for temperature control. For separation purposes, we used an IonPac AG17 guard

2 column in conjunction with an IonPac AS17 analytical column, and with an anion self-

3 regenerating suppressor that operated at $248 \mathrm{~mA}$ in recycled-water mode. The guard and

4 analytical columns, both maintained at $35{ }^{\circ} \mathrm{C}$, were 4 -mm inner diameter, and 50-mm-long. We

5 employed an EG50 eluent generator with an EGC-KOH cartridge and a CR-ATC (continuously

6 regenerated anion trap column) to achieve a gradient separation by producing a varying

7 concentration of $\mathrm{KOH}$ (from deionized water) over the run at a flow rate of $1.0 \mathrm{~mL} / \mathrm{min}$.

8 To measure low (sub-ppb) concentrations of $\mathrm{I}^{-}$, we used the ED50A electrochemical

9 detector in pulsed amperometric mode (i.e., silver working electrode and $\mathrm{Ag} / \mathrm{AgCl}$ reference

10 electrode), after separation using IonPac AG11 and IonPac AS11 columns. Iodide separation was

11 achieved with $50 \mathrm{mM}$ nitric acid eluent under an isocratic flow of $1.5 \mathrm{~mL} / \mathrm{min}$ (Dionex 2004).

12 We used a $25 \mu \mathrm{L}$ injection loop sizefor sample analyses for both conductivity and amperometry

13 detection and Dionex PeakNet 6.2 software for system control, data collection, and processing.

14 Measurement of 4-iodoaniline was carried out using a quadrupole inductively coupled

15 plasma-mass spectrometry (ICP-MS) system (Hewlett Packard 4500, Agilent Technologies,

16 Palo Alto, CA). The ICP-MS was operated at a forward power of $1,400 \mathrm{~W}$ with argon flow rates

17 of $16,1.0$, and $0.9 \mathrm{~L} / \mathrm{min}$, respectively for plasma, auxiliary gas, and carrier gas flows. The

18 column effluent sample was spiked with $20 \mathrm{ng} / \mathrm{L}$ internal standard elements for iodine-127

19 analysis. A rinse solution of $10 \%$ methanol was used between samples to mitigate potential

20 memory effects. For ICP-MS analysis of total iodine (in this study, introduced as 4-iodoaniline),

21 we tested several internal standards (Y-89, Rh-103, In-115, Tb-159, and Bi-209) to examine

22 potential matrix effects introducted by the effluent samples collected from column transport

23 studies. Rh-103 consistently stood out as the best choice for all samples types, and was therefore

24 used in the iodine data reduction. 


\section{$1 \quad 3$. Results and Discussion}

2 3.1. Analyses of Iodine Species by Ion Chromatography

Employment of recently developed, specialized ion chromatographic methods was a key

4 factor in obtaining the experimental results descrived here. As shown in Figure 1a, under a

5 hydroxide gradient condition at a range of 2 to $60-\mathrm{mM} \mathrm{KOH}$, one can use conductivity detection

6 to resolve and quantify $\mathrm{IO}_{3}^{-}$(early arrival) and $\mathrm{I}^{-}$(late arrival), as well as other common anions

7 such as fluoride, chloride, and sulfate. This method has a detection limit of 21.7 for $\mathrm{IO}_{3}{ }^{-}$and 19.9

$8 \mu \mathrm{g} / \mathrm{L}$ for $\mathrm{I}^{-}$(Hu and Moran 2004).

At lower concentrations, the amperometric method provides a fast (run time less than 4

10 minutes) and sensitive way to determine $\mathrm{I}^{-}$concentration. We followed the experimental

11 conditions for pulsed amperometric detection, published by Dionex (2004), with an example

12 chromatogram shown in Figure 1b. Fluoride, chloride, bromide, and iodate all elute well before

13 iodide. Amperometric detection with a silver electrode is highly specific for iodide, with a

14 measured method detection limit of $0.6 \mu \mathrm{g} / \mathrm{L}$. Minimal memory effect was observed, as

15 evidenced by a measured apparent iodide concentration only $0.005 \%$ for the first non-iodide-

16 containing sample injected immediately after a high-concentration (100 mg/L) iodide standard.

\section{3.2. Conversion of Iodate to Iodide}

Figure 2 shows breakthrough curves for $\mathrm{I}^{-}$and $\mathrm{IO}_{3}{ }^{-}$, which were simultaneously injected,

19 in a column packed with SRS surface soil (results for transport of 4-iodoaniline are discussed

20 later). It is evident that the eluted iodide is more than that pumped into the column, with a mass

21 recovery of $129 \%$, compared to $100 \%$ for tritium (Table 2). Both conductivity and amperometric

22 detection methods confirm the larger mass recovery for $\mathrm{I}^{-}$. The breakthrough curve obtained by

23 pumping $\mathrm{I}^{-}$alone produced a steady-state plateau lower than the inlet concentration and a

24 corresponding mass recovery of $94 \%$, implying that a portion of $\mathrm{I}^{-}$is irreversibly retained. The 
1 retention of $\mathrm{I}^{-}$, with or without simultaneous transport of $\mathrm{IO}_{3}^{-}$, in the SRS surface soil is small,

2 with a retardation factor of about 0.93 , as compared to 0.95 for tritium (Table 2). The retardation

3 factor and mass recovery are calculated by moment analysis of the breakthrough curves.

We also conducted a transport experiment of $\mathrm{IO}_{3}^{-}$at a concentration of $10^{-5} \mathrm{M}(1.54$

$5 \mathrm{mg} / \mathrm{L}$, ppm; see Figure 3). While the $\mathrm{IO}_{3}{ }^{-}$concentration in the column effluent was quantified by

6 conductivity detection, $\mathrm{I}^{-}$production was monitored by the more sensitive amperometric method.

7 It is apparent that production of $\mathrm{I}^{-}$takes place after the appearance of $\mathrm{IO}_{3}^{-}$. The effluent mass

8 recovery for $\mathrm{IO}_{3}{ }^{-}$is $82 \%$, the corresponding $\mathrm{IO}_{3}{ }^{-}$portion from produced $\mathrm{I}^{-}$is calculated to be

$96.1 \%$, and the remainder (about 12\%) is retained irreversibly in the sample column or lost as

10 volatile iodine $\left(\mathrm{I}_{2}\right)$ during the reduction. In contrast to the low retention of $\mathrm{I}^{-}$in SRS surface soil

11 (Figure 2), $\mathrm{IO}_{3}^{-}$exhibits delayed transport with some sorption, which will be discussed later. As

$12 \mathrm{IO}_{3}{ }^{-}$is transported through the SRS surface soil column, a fraction of sorbed $\mathrm{IO}_{3}{ }^{-}$is converted to

$13 \mathrm{I}^{-}$, which quickly elutes from the column because of its minimal interaction with the solids.

14 We carried out batch experiments to examine the surface-mediated $\mathrm{IO}_{3}{ }^{-}$reduction in the

15 presence of the four sediments from the SRS and Hanford Sites, as well as with several clay

16 mineral separates that are suspected of facilitating the reduction. As discussed in Section 2,

17 Materials and Methods, we conducted four treatments, including control, blank, iodide, and

18 iodate. As shown in Figure 4, the presence of $\mathrm{IO}_{3}{ }^{-}$does not interfere with the detection of $\mathrm{I}^{-}$.

19 Figure 5 presents the results of batch experiments for SRS surface soil and Hanford sediment.

20 Figure 5a confirms the same $\mathrm{IO}_{3}^{-}$reduction to $\mathrm{I}^{-}$in the SRS surface soil that was observed in the

21 column experiment. Such reduction also occurs in Hanford sediment (Figure 5b).

Iodide was not detected during any of the blank treatments; however, this is not

23 unexpected because the water-leachable iodide on sediment surfaces was too low to be measured 
1 under the experimental conditions, given that the total iodine content for typical soils ranges

2 from $<1$ to $20 \mathrm{mg} / \mathrm{kg}$ (Whitehead 1973; Fuge and Johnson 1986). The organically-bound iodine,

3 which is probably present in at least the SRS surface soil sample, may not be leached or

4 detected.

5 Furthermore, while the observed $\mathrm{I}^{-}$peak height from the $\mathrm{IO}_{3}^{-}$treatment indicates the 6 magnitude of $\mathrm{IO}_{3}^{-}$reduction, the difference in peak responses from the iodide treatments is

7 related to the affinity of each sample to sorb $\mathrm{I}^{-}$. For example, kaolinite sorbs $\mathrm{I}^{-}$to a greater

8 degree than does illite and therefore we observed a smaller $\mathrm{I}^{-}$peak from the iodide treatment. On

9 the other hand, illite exhibits a greater capacity for reducing $\mathrm{IO}_{3}{ }^{-}$to $\mathrm{I}^{-}$.

We conducted similar studies for the clay mineral separates that are important in natural

11 media, and example chromatograms for kaolinite and illite are shown in Figure 6. Table 3 lists

12 the $\mathrm{IO}_{3}{ }^{-}$reduction capacity for the samples tested. Illite, montomorillonite, and kaolinite show an

13 appreciable capability for $\mathrm{IO}_{3}{ }^{-}$reduction, while vermiculite is incapable of the reduction. Iodate

14 reduction in the four sediments at SRS and Hanford is probably related to the presence of these

15 minerals, as shown from the clay mineralogy obtained by x-ray diffraction (Table 1). While the

16 presence of aqueous-phase reducing agents or microbes can contribute to $\mathrm{IO}_{3}{ }^{-}$reduction, they are

17 unlikely to be factors in this study because the soil samples had been air-dried for nearly two

18 years, which is not conductive to the survival of microbes (Wollum 1994), and the batch

19 experiment was conducted under atmospheric conditions.

It is probable that the abiotic reduction was mediated by structural iron $(\mathrm{Fe})$ present in

21 some clay minerals. Some of the most abundant natural reductants are soil clay minerals that

22 contain reduced forms of iron and sulfur. Such minerals have been shown to reductively

23 transform organic and inorganic contaminants, including tetrachloroethylene, chloropicrin, and 
1 Cr(VI) (Stucki et al. 1996; Erbs et al. 1999; Cervini-Silva et al. 2000; Stucki et al. 2002; Lee and

2 Batchelor 2003). However, we are not aware of any published studies evaluating the capacity for

3 clay minerals to abiotically reduce $\mathrm{IO}_{3}{ }^{-}$to $\mathrm{I}^{-}$. Using x-ray absorption near edge structure

4 (XANES), which requires a relatively high concentration ( $0.009 \mathrm{M}$ iodine as $\left.\mathrm{IO}_{3}{ }^{-}\right)$, Furhrmann et

5 al. (2000) reported that $\mathrm{IO}_{3}{ }^{-}$was reduced to what appeared to be $\mathrm{I}_{2}$ or $\mathrm{HI}$ vapor in the presence of

6 pyrite; no similar change in the iodine redox state was observed in magnetite and biotite

7 experiments. Fukui et al. (1996) found that $\mathrm{I}^{-}$accounted for about $30 \%$ total iodine, with $\mathrm{IO}_{3}{ }^{-}$as

8 the starting species, in a solution after a 14-day contact with a Japanese soil; no explanation for

9 the reduction was offered. Muramatsu et al. (1990) reported that $\mathrm{IO}_{3}^{-}$was mostly (68-95\%)

10 converted to $\mathrm{I}^{-}$after an 8-day contact with three Japanese soils, and there was a negligible

11 change for $\mathrm{I}^{-}$.

The term illite was originally introduced to cover all clay-sized minerals belonging to the

13 mica group that contain structural Fe (Drever 1997; Sparks 2003). Montmorillonite is an

14 important mineral in the smectite group, and is the term that has been traditionally used for all

15 smectite minerals. Compositional variations in the smectite group are enormous, resulting from

16 substitution of different amounts of $\mathrm{Mg}^{2+}, \mathrm{Al}^{3+}, \mathrm{Fe}^{2+}, \mathrm{Fe}^{3+}$, and $\mathrm{Li}^{+}$and other cations in the

17 octahedral layer, and substitution of $\mathrm{Al}^{3+}$, and probably $\mathrm{Fe}^{3+}$, for $\mathrm{Si}^{2+}$ in the tetrahedral layer. Iron

18 is the most frequently reported element substituted in kaolinite, and the presence of structural

19 iron has been proven using various analytical methods (Dixon 1989). Although vermiculite is an

20 iron-bearing mineral, structural Fe(II) may not be as reactive as for other soil minerals tested,

21 including montmorillonite (Lee and Batchelor 2003). In this study, we did not observe $\mathrm{IO}_{3}^{-}$

22 reduction to $\mathrm{I}^{-}$by vermiculite, which is consistent with the nonreactivity of structural $\mathrm{Fe}(\mathrm{II})$

23 observed by Lee and Batchelor (2003). We cannot rule out the possibility of $\mathrm{IO}_{3}{ }^{-}$reduction to 
1 the intermediate valence states $(+1,0)$ of iodine, nevertheless, we did not observe any brownish

2 colored solution (from $\mathrm{I}_{2}$ ).

3 We did not detect oxidation of $\mathrm{I}^{-}$to $\mathrm{IO}_{3}^{-}$, which is consistent with results reported for

4 Japanese soils by Muramatsu et al. (1990). However, this result is not conclusive because of the

5 limitations in analytical methods that distinguish $\mathrm{IO}_{3}{ }^{-}$and $\mathrm{I}^{-}$(and iodine species in general) at

6 low concentrations in complex matrices. The IC-conductivity method can separate and quantify

7 both $\mathrm{IO}_{3}{ }^{-}$and $\mathrm{I}^{-}$with a reasonably low detection limit, but the aqueous phase from the batch

8 experiments contained some impurities (most likely low-molecular-weight organic acids, such as

9 acetate, propionate, and formate) that often interfered with the iodate peak. For the IC-

10 amperometric method for $\mathrm{I}^{-}$detection, we converted $\mathrm{IO}_{3}^{-}$, which is potentially present, to $\mathrm{I}^{-}$by

11 adding $0.1 \mathrm{~mL} 0.1 \mathrm{M} \mathrm{NaHSO}_{3}$ (a reducing agent) to $1 \mathrm{~mL}$ solutions obtained from iodide-

12 treatment. No significant change was observed, but this may be due to masking of a small

13 amount of $\mathrm{IO}_{3}^{-}$, if present, by a much greater amount of $\mathrm{I}^{-}$. Overall, further development of

14 sensitive and specific analytical methods for different iodine species in complex matrices is 15 warranted.

16 3.3. Physicochemical Properties Affecting Sorption and Transport of Iodine Species

17 A bicontinuum model based on first-order mass transfer was used to analyze the results

18 of the experiments, and sorption was conceptualized to occur in two (instantaneous and rate-

19 limited) domains (Brusseau and Rao 1989). Detailed mathematical description of the model are

20 presented, for example, in Hu and Brusseau (1998). Four important sorption parameters are

21 briefly mentioned here; $R_{f}$ is the retardation factor that indicates the magnitude of sorption, $F$ is

22 the fraction of sorbent for which sorption is instantaneous, $\mathrm{N}$ is the Freundlich exponent which

23 characterizes the degree of sorption nonlinearity, and $k_{2}$ is first-order desorption rate coefficients

$24\left(\mathrm{~T}^{-1}\right)$. The value of $k_{2}$ specifies the degree of nonequilibrium existent in the system, which 
1 decreases as $k_{2}$ increases in magnitude. The retardation factor and mass recovery are calculated

2 by moment analysis of the breakthrough curves. Other sorption parameters are obtained using

3 FITNLE, a nonlinear least-squares program that includes nonlinear sorption (Jessup et al. 1989).

4 Results from the column experiments for these parameters are presented in Table 2.

5 In all the samples, tritium exhibited ideal breakthrough with symmetrical behavior and

6 negligible tailing (examples are shown in Figures 2 and 7) and conservative (not retarded)

7 transport (Table 2). Iodide sorption onto many types of geologic media has been reported to be

8 extremely limited (Whitehead 1974; Kaplan et al. 2000; Turin et al. 2002). We observed very

9 limited sorption of $\mathrm{I}^{-}$during transport in SRS surface soil, SRS aquifer, and Hanford sediment

10 samples (Figures 8-10 and Table 2). However, there was significantly retarded transport of $\mathrm{I}^{-}$,

11 compared to tritium, in the SRS subsoil sample (Figure 7). This sample contained an appreciable

12 amount of iron and aluminum oxide minerals (Table 1), which possess positively charged

13 surfaces and contribute to anion sorption, as confirmed from anion exchange capacity (AEC)

14 measurements. Significant $\mathrm{I}^{-}$sorption has been observed in volcanic soils (Yu et al. 1996),

15 including frequent observation of $\mathrm{I}^{-}$sorption in Japanese soils (Yoshida et al. 1992; 1998). These

16 soils contain substantial amounts of imogolite, ferrihydrite, and allophane, all of which have

17 appreciably positively charged surfaces under acidic conditions.

18 We used selective extraction to target the different fractions of Fe in the SRS subsoil

19 sample. For example, citrate-bicarbonate-dithionite (CBD) extractable Fe contains crystalline

20 iron oxide minerals such as hematite, goethite, lepidocrocite, and ferrihydrite, while ammonium

21 oxalate $\left(\mathrm{NH}_{4}-\mathrm{Ox}\right)$ extraction targets noncrystalline Fe oxides, including ferrihydrite and

22 ferrihydrite-like minerals (Loeppert and Inskeep 1996). The $\mathrm{CBD}$ and $\mathrm{NH}_{4}-\mathrm{Ox}$ extractions also

23 remove some crystalline and noncrystalline aluminum oxide phases, respectively. The SRS

24 subsoil had a relatively high crystalline Fe and $\mathrm{Al}$ oxide content from CBD extraction (Table 1). 
1 The anion sorption capacity of each geologic medium was reflected in the AEC value, which

2 was measured according to the unbuffered salt extraction method of Summer and Miller (1996).

3 As presented in Table 1, the SRS subsoil has a significant AEC (4.04 meq/100 g sample); more

4 than ten times higher than other samples.

5 Iodate commonly exhibits more retarded transport than iodide because it interacts more

6 strongly with clays and organic matter (Couture and Seitz 1983; Ticknor and Cho 1990;

7 Sheppard and Thibault 1992; Yoshida et al. 1998). As discussed by Kaplan et al. (2000), the

8 cause for the difference in $\mathrm{I}^{-}$and $\mathrm{IO}_{3}{ }^{-}$sorptive behavior is not known but is presumably the

9 result of the harder base nature of $\mathrm{IO}_{3}^{-}$, as compared to $\mathrm{I}^{-}$, which would favor hard-hard

10 interactions with the hard acid sites on the mineral surfaces. The disparate sorption behavior of $\mathrm{I}^{-}$

11 and $\mathrm{IO}_{3}^{-}$was confirmed in our study, which consistently showed greater sorption of $\mathrm{IO}_{3}^{-}$than

12 for $\mathrm{I}^{-}$. Even in the Hanford sediment, which has a very low AEC, noticeable sorption of $\mathrm{IO}_{3}{ }^{-}$

13 took place (Table 2).

14 Organically-bound iodine can be a significant fraction of total iodine in aqueous systems

15 and in the atmosphere. For example, methyl iodide is an important gaseous form of iodine in the

16 marine atmosphere and in releases from nuclear fuel reprocessing facilities, while dissolved

17 organo-I compounds comprise up to $50 \%$ of total iodine in aqueous samples from estuaries,

18 rivers, and rain (Santschi and Schwer 2004). Experiments evaluating the transport of

19 organoiodine compounds are scarce, given the challenges associated with monitoring

20 organoiodine compounds. In this study, we used 4-iodoaniline as a representative nonvolatile

21 organoiodine species. As expected, we found that transport of 4-iodoaniline is different from the

22 inorganic forms, $\mathrm{I}^{-}$and $\mathrm{IO}_{3}^{-}$, and seems to be related to the amount of organic matter in the

23 sample. This finding is consistent with the hydrophobicity of organoiodine and its affinity for

24 hydrophobic organic matter (Brusseau and Rao 1989). In SRS surface soil with $2.33 \%$ organic 
1 matter, transport of 4-iodoaniline is delayed by more than twenty times, as compared to $\mathrm{I}^{-}$

2 (Figure 2 and Table 2). Such disparate behavior for the different iodine species needs to be

3 considered when studying the behavior of iodine because inorganic iodine could be fixed onto

4 macromolecular humic substances, as reported by Tikhomirov et al. (1980) and Rädlinger and

5 Heumann (2000), and this fixation changes the physicochemical characteristics and associated

6 fate and transport behavior of iodine. In contrast to surface soil results, 4-iodoaniline migrates

7 without retardation, similar to tritium, in the SRS subsoil, while $\mathrm{IO}_{3}{ }^{-}$and $\mathrm{I}^{-}$are significantly

8 retarded (Figure 7). This is also true for the SRS aquifer material, though the magnitude of

9 sorption for $\mathrm{IO}_{3}{ }^{-}$and $\mathrm{I}^{-}$is less than for SRS subsoil (Figure 9). Both SRS subsoil and SRS

10 aquifer samples have extremely low organic matter contents (Table 1).

11 Numerical fitting of the 4-iodoaniline breakthrough curve in SRS surface soil shows

12 nonlinear (Freundlich exponent $\mathrm{N}$ value 0.48 ) and rate-limited (desorption rate coefficient $k_{2}$

$130.03 \mathrm{~h}^{-1}$ ) sorption processes. Intraorganic matter diffusion is probably responsible for the rate-

14 limited sorption by materials containing moderate levels of organic matter (e.g., $>0.1 \%$ ), as

15 reported, for example, by Brusseau and Rao (1989) and Hu et al. (1995).

\subsection{Effect of Input Concentration and Residence Time}

17 In addition to iodine speciation, varying the input concentration also likely has an effect

18 on iodine sorption and transport behavior. Because the sorption of both $\mathrm{I}^{-}$(especially) and $\mathrm{IO}_{3}{ }^{-}$is

19 related to the presence and magnitude of soil components that possess positively-charged

20 surfaces and because the positively-charged surface sites are limited, the extent of sorption will

21 probably be affected by the input concentration. Positively-charged adsorption sites may exist on

22 the edges of 2:1 clays (such as smectite and illite), on Al- and Fe-oxide surfaces, and on 1:1

23 clays (such as kaolinite). The number of sorption sites in variable-charge minerals is influenced

24 by ionic strength, solution $\mathrm{pH}$, and counterion valance (Seaman et al. 1996). 
Ideally, one would use a concentration that is comparable to real-world situations, i.e.

$210^{-8} \mathrm{M}$ for stable iodine in the hydrosphere (Fuge and Johnson 1986) and a few orders-of-

3 magnitude lower for anthropogenic ${ }^{129}$ I such as in SRS (e.g., Beals and Hayes 1995). However,

4 for trace concentrations of $\mathrm{I}^{-}$(usually introduced as radioactive ${ }^{125} \mathrm{I}$ in laboratory experiments) in

5 a system open to air, the $\mathrm{I}^{-}$can be oxidized to $\mathrm{IO}_{3}^{-}$(Couture and Seitz 1983; Fuhrmann et al.

6 1998), which will complicate the data interpretation, considering the different sorption behavior

7 of $\mathrm{I}^{-}$and $\mathrm{IO}_{3}^{-}$. It is not improbable that observed sorption of iodide is actually the result of

8 conversion to $\mathrm{IO}_{3}{ }^{-}$and subsequent sorption.

9 At this point, we turn the discussion to the results of two iodine concentrations $(0.1 \mathrm{mM}$

10 and $0.01 \mathrm{mM}$ ) in the SRS sediments. We used a $\mathrm{CaCl}_{2}$ electrolyte solution with a concentration

11 of $\mathrm{Cl}^{-}$equivalent to the inorganic iodine species $\left(\mathrm{I}^{-}\right.$and $\left.\mathrm{IO}_{3}^{-}\right)$. By thus avoiding anion

12 competition, we were able to directly examine the sorption affinity of iodine species. $\mathrm{I}^{-}$at the

13 two initial concentrations in SRS surface soil was not sorbed on the soil (Table 2). However,

14 some portion of $\mathrm{I}^{-}$is irreversibly retained by the soil or lost via some unknown mechanism,

15 which may be related to the concentration, beacause more retention/loss was noticed at the

16 higher concentration $(0.1 \mathrm{mM})$. Iodate sorption was similar between the two initial

17 concentrations (Table 2), although $\mathrm{IO}_{3}{ }^{-}$reduction to $\mathrm{I}^{-}$was more apparent at the lower

18 concentration, indicating a limited reduction capacity of the medium. A lower initial $\mathrm{I}^{-}$

19 concentration in SRS subsoil produced more irreversible retention/mass loss, similar to what is

20 observed in SRS surface soil. There was no breakthrough curve for $\mathrm{IO}_{3}{ }^{-}$at either concentration

21 because of the high anion sorption capacity of the sample, as well as the greater sorption

22 potential of $\mathrm{IO}_{3}^{-}$compared to $\mathrm{I}^{-}$.

23 Iodate sorption and transport in the SRS aquifer material at the two initial concentrations

24 is well described by nonlinear and rate-limited sorption with two sorption domains (Table 2 and 
1 Figure 9). Values of $F$, the fraction of sorbent for which sorption is instantaneous, are the same

2 for the two concentrations. As expected, the Freundlich $\mathrm{N}$ value is smaller, indicative of more

3 nonlinearity at the higher initial concentration. The value of $k_{2}$ decreases as input concentration

4 decreases, consistent with previous findings (e.g., Hu and Brusseau 1998). The trend of $\mathrm{I}^{-}$and

$5 \mathrm{IO}_{3}{ }^{-}$sorption with respect to the initial concentration seems to be consistent with the limited

6 number of positively-charged sites for sorption, as discussed above. Greater $\mathrm{I}^{-}$sorption at a much

7 lower $\left(10^{-12} \mathrm{M}\right)$ concentration for three subsurface sediments from the Hanford Site was reported

8 by Kaplan et al. (2000).

9 The column experiments with the Hanford sediment did not indicate the appreciable

10 reduction of $\mathrm{IO}_{3}^{-}$to $\mathrm{I}^{-}$, as observed in batch tests. The treatments, however, between column and

11 batch tests are different, with the sediment-packed column having been pre-equilibrated with the

12 same molarity of chloride before the transport experiments.

13 In addition - and probably more important than pretreatment - the difference in contact

14 time between column ( $\sim 1 \mathrm{hr}$ ) and batch ( $24 \mathrm{hrs})$ tests, as well as the mixing condition, also

15 affects the magnitude of $\mathrm{IO}_{3}^{-}$reduction. Figure 11 shows $\mathrm{I}^{-}$and $\mathrm{IO}_{3}{ }^{-}$breakthrough curves for

16 SRS surface soil for two residence times, achieved by changing the experimental pore-water

17 velocity. We observed greater $\mathrm{IO}_{3}{ }^{-}$loss, specifically a mass recovery of 0.80 compared to 0.97 ,

18 at the longer residence time, which coincides with a larger $\Gamma^{-}$mass recovery, 0.71 vs. 0.66 . The

19 retardation factor at the longer residence time is also somewhat larger (3.6 vs. 2.3) than that

20 obtained at the shorter residence time, suggesting that, while undergoing partial conversion, $\mathrm{IO}_{3}{ }^{-}$

21 sorption is rate-limited.

\section{4. Conclusions}

23 In this study, we examined the sorption and transport behavior of three iodine species

24 (iodide, iodate, and 4-iodoaniline) in several subsurface geological media collected at SRS and 
1 the Hanford Site, where anthropogenic ${ }^{129}$ I from prior fuel processing activities poses an

2 environmental concern. The geologic media display significant differences in organic matter

3 content, clay mineralogy, soil $\mathrm{pH}$, and texture. We conducted both column and batch

4 experiments to investigate the complex sorption and transport processes that occur, which

5 include $\mathrm{IO}_{3}^{-}$reduction, irreversible retention or mass loss of $\mathrm{I}^{-}$, and rate-limited and nonlinear

6 sorption.

$7 \quad$ We observed appreciable $\mathrm{IO}_{3}^{-}$reduction to $\mathrm{I}^{-}$, probably mediated by structural $\mathrm{Fe}(\mathrm{II})$, in

8 experiments with certain clay minerals. We also considered other experimental variables, such as

9 the initial iodine concentration. Examination of iodine speciation, with due attention to potential

10 interconversion among species, is essential when interpreting the environmental behavior of

11 iodine. The different iodine species exhibit very different sorption and transport behavior in three

12 geologic samples collected from different depths at SRS. Consequently, anthropogenic ${ }^{129}$ I has

13 different residence times as the different species migrate through the various sediment types.

14 Results obtained from this study yield valuable insight into processes and mechanisms affecting

15 the geochemical cycling of iodine in the environment and provide key parameters (rate of

16 transport and extent of sorption) for risk assessment at these sites.

\section{Acknowledgements}

18 This work was supported by the Laboratory Directed Research and Development

19 program at Lawrence Livermore National Laboratory (LLNL). We gratefully acknowledge John

20 Zachara of the Pacific Northwest National Laboratory for providing the Hanford sample used in

21 the experiments described in this paper. William Austin of Oregon State University provided

22 assistance in analyzing some properties of the solid samples. This work was performed under the

23 auspices of the U.S. Department of Energy by the University of California, Lawrence Livermore 
1 National Laboratory under Contract W-7405-Eng-48. The authors thank Karen Rath for helpful 2 comments. 


\section{References}

2 ASTM. 1998. Standard test method for 24-hour batch-type measurement of contaminant sorption

3 by soils and sediments (D4646-87). Annual Book of ASTM Standards. 04.08. pp 44-47.

$4 \quad$ Philadelphia, PA, American Society for Testing and Materials.

5 Baker, A. R., C. Tunnicliffe and T. D. Jickells. 2001. Iodine speciation and deposition fluxes

6 from the marine atmosphere. J. Geophy. Res. - Atmospheres 106(D22), 28743-28749.

7 Beals, D. M. and D. W. Hayes. 1995. Technetium-99, iodine-129 and tritium in the waters of the 8 Savannah River Site. Sci. Total Environ, 173/174, 101-115.

9 Brusseau, M. L., and P. S. C., Rao. 1989. Sorption nonideality during organic contaminant

10 transport in porous media. CRC Crit. Rev. Environ. Control 19:33-99.

11 Cervini-Silva, A., J. Wu, R. A. Larson, and J. W. Stucki. 2000. Transformation of chloropicrin in 12 the presence of iron-bearing clay minerals. Environ. Sci. Technol. 34(5), 915-917.

13 Couture, R. A. and M. G. Seitz. 1983. Sorption of anions of iodine by iron oxides and kaolinite. $14 \quad$ Nucl. Chem. Waste Manage. 4, 301-306.

15 Dionex Corp. 2004. The determination of iodide in milk products. Application Note 37.

16 Available at http://www1.dionex.com/en-

17 us/webdocs/application/industry/foodbev/ic/AN37 V19.pdf.

18 Dixon, J. B. 1989. Kaolin and serpentine group minerals. Minerals in Soil Environments pp 467-

19 525, J. B. Dixon and S. B. Weed, Eds. Madison, WI, Soil Science Society of America, Inc.

20 Drever, J. I. 1997. The Geochemistry of Natural Waters: Surface and Groundwater

21 Environments. Third Edition. Upper Saddle River, NJ, Prentice-Hall. 
1 Erbs, M., H. C. B. Hansen and C. E. Olsen. 1999. Reductive dechlorination of carbon tetrachloride using iron(II) iron(III) hydroxide sulfate (green rust). Environ. Sci. Technol. 33(2), 307-311.

4 Edwards, R. R. 1962. Iodine-129: Its occurrence in nature and utility as a tracer. Science, 137, $851-853$.

6 Fréchou, C. and D. Calmet. 2003. ${ }^{129}$ I in the environment of the La Hague nuclear fuel 7 reprocessing plant-from sea to land. J. Environ. Radioactivity 70, 43-59.

8 Fuge, R. C. and C. Johnson. 1986. The geochemistry of iodine - A review. Environ. Geochem. $9 \quad$ Health, 8(2), 31-54.

10 Fukui, M., Y. Fukikawa and N. Satta. 1996. Factors affecting interaction of radioiodide and 11 iodate species with soil. J. Environ. Qual. 31(2), 199-216.

12 Fuhrmann, M., S. Bajt and M. A. A. Schoonen. 1998. Sorption of iodine on minerals 13 investigated by $\mathrm{x}$-ray absorption near edge structure (XANES) and ${ }^{125} \mathrm{I}$ tracer sorption 14 experiments. Appl. Geochem. 13(2), 127-141.

15 Hou, X., X. Yan and C. Chi. 2000. Chemical species of iodine in some seaweeds. II. Iodine bound macromolecules. J. Radioanal. Nucl. Chem. 245(3), 461-467.

$17 \mathrm{Hu}, \mathrm{Q} ., \mathrm{X}$. Wang, and M. L. Brusseau. 1995. Quantitative structure-activity relationships for 18 evaluating the influence of sorbate structure on sorption of organic compounds by soil. 19 Environ. Toxicol. Chem. 14(7), 1133-1140. 
$1 \mathrm{Hu}, \mathrm{Q}$. and M. L. Brusseau. 1998. Coupled effect of nonlinear, rate limited sorption and

2 biodegradation on transport of 2,4-dichlorophenoxyacetic acid in soil. Environ. Toxicol.

3 Chem. 17(9), 1673-1680.

$4 \mathrm{Hu}, \mathrm{Q}$. and J. E. Moran. 2004. Simultaneous analyses and applications of multiple

5 fluorobenzoate and halide tracers in hydrologic studies. Hydrologic Processes (submitted).

6 Jessup, R. E., M. L. Brusseau, and P. S. C. Rao. 1989. Modeling solute transport. Florida

7 Agricultural Experimental Station Publication, University of Florida, Gainesville, FL.

8 Kaplan, D. I., R. J. Serne, K. E. Parker, and I. V. Kutnyakov. 2000. Iodide sorption to subsurface

9 sediments and illitic minerals. Environ. Sci. Technol. 24(3), 399-405.

10 Kaplan, D. I. 2003. Influence of surface charge of an Fe-oxide and an organic matter dominated 11 soil on iodide and pertechnetate sorption. Radiochim. Acta 91(3), 173-178.

12 Kekli, A., A. Aldahan, and M. Meili. 2003. I-129 in Swedish rivers: Distribution and sources. 13 Sci. Total Environ. 309(1-3), 161-172.

14 Klute, A., Ed. 1986. Methods of Soil Analysis: Physical and Mineralogical Methods. Part 1.

15 Second Edition. Madison, Wisconsin, Soil Science Society of American, Inc.

16 Lee, W. and B. Batchelor. 2003. Reductive capacity of natural reductants. Environ. Sci. Technol. $17 \quad 37(3), 535-541$.

18 Liss, P. S., J. R. Herring, and E. D. Goldberg. 1973. The iodide/iodate system in seawater as a 19 possible measure of redox potential. Nature 242(120), 108-109. 
1 Loeppert, R. L. and W. P. Inskeep. 1996. Iron. Methods of Soil Analysis: Chemical Methods.

2 Part 3. pp 639-664 D. L. Sparks, Ed. Madison, Wisconsin, Soil Science Society of $3 \quad$ American, Inc.

4 Moran, J. E., U. Fehn, and R. T. D. Teng. 1998. Variations in I-129/I-127 ratios in recent marine 5 sediments: Evidence for a fossil organic component. Chem. Geol. 152(1-2), 193-203.

6 Moran, J. E., S. Oktay, P. H. Santschi, and D. R. Schink. 1999. Atmospheric dispersal of

$7 \quad{ }^{129}$ Iodine from nuclear fuel reprocessing facilities. Environ. Sci. Technol. 33(15), 253682542 .

9 Moridis, G. J., Q. Hu, Y. S. Wu, and G. S. Bodvarsson. 2000. Modeling studies of radionuclide 10 transport in the unsaturated zone of Yucca Mountain, Nevada. LBNL-45870. Lawrence 11 Berkeley National Laboratory, Berkeley, CA.

12 Muramatsu, Y. and Y. Ohmono. 1988. Tracer experiments for the determination of the chemical 13 forms of radioiodine in water samples. J. Radioanl. Nucl. Chem. 124: 123-134.

14 Muramatsu, Y., S. Uchida, P. Sriyotha, and K. Sriyotha. 1990. Some considerations on the 15 sorption and desorption phenomena of iodide and iodate on soil. Water, Air Soil Pollu. $16 \quad 49(1-2), 125-138$.

17 National Research Council (NRC). 2000. Research Needs in Subsurface Science. U.S. 18 Department of Energy's Environmental Management Science Program. Washington, D.C., $19 \quad$ National Academy Press.

20 Oktay, S. D., P. H. Santschi, J. E. Moran, and P. Sharma. 2001. ${ }^{129}$ I and ${ }^{127}$ I transport in the 21 Mississippi River. Environ. Sci. Technol. 35, 4470-4476. 
1 Rädlinger, G. and K. G. Heumann. 2000. Transformation of iodide in natural and wastewater systems by fixation on humic substances. Environ. Sci. Technol. 34(18), 3932-3936.

3 Santschi, P.H., and K.A. Schwehr. 2004. ${ }^{129} \mathrm{I} /{ }^{127} \mathrm{I}$ as a new environmental tracer or

4 geochronometer for biogeochemical or hydrodynamic processes in the hydrosphere and 5 geosphere: The central role of organo-iodine. Sci. Tot. Environ., in press, corrected proof 6 available on-line at www.sciencedirect.com.

7 Seaman, J. C., P. M. Bertsch, S. F. Korom, and W. P. Miller. 1996. Physicochemical controls on 8 nonconservative anion migration in coarse-textured alluvial sediments. Ground Water 34(5), $9 \quad 778-783$.

10 Sheppard, M. I. and D. H. Thibault. 1992. Chemical behavior of iodine in organic and mineral 11 soils. Appl. Geochem. 7, 265-272.

12 Sheppard, M. I., J. L. Hawkins, and P. A. Smith. 1996. Linearity of iodine sorption and sorption 13 capacities for seven soils. J. Environ. Qual. 25, 1261-1267.

14 Sparks, D. L., Ed. 1996. Methods of Soil Analysis: Chemical Methods. Part 3. Madison, 15 Wisconsin, Soil Science Society of American, Inc.

16 Sparks, D. L. 2003. Environmental Soil Chemistry. Second Edition. San Diego, Academic Press.

17 Stucki, J. W., G. W. Bailey and H. M. Gan. 1996. Oxidation-reduction mechanisms in iron18 bearing phyllosilicates. Appl. Clay Sci. 10(6), 417-430.

19 Stucki, J. W., K. Lee, L. Z. Zhang, and R. A. Larson. 2002. Effects of iron oxidation state on the 20 surface and structural properties of smectites. Pure Appl. Chem. 74(11), 2145-2158. 
1 Summer, M. E. and W. P. Miller. 1996. Cation exchange capacity and exchange coefficients.

2 Methods of Soil Analysis: Chemical Methods. Part 3. pp 1201-1229. D. L. Sparks, Ed.

3 Madison, Wisconsin, Soil Science Society of American, Inc.

4 Ticknor, K. V. and Y. H. Cho. 1990. Interaction of iodide and iodate with granitic fracture-filling 5 minerals. Radioanal. Nucl. Chem. 140(1), 75-90.

6 Tikhomirov, F. A., S. V. Kasparov, B. S. Prister, and V. G. Sal'nikov. 1980. Role of organic 7 matter in iodine fixation in soils. Soviet Soil Sci. 2, 54-62.

8 Turin, H. J., A. R. Groffman, L. E. Wolfsberg, J. L. Roach, and B. A. Strietelmeier. 2002. Tracer 9 and radionuclide sorption to vitric tuffs of Busted Butte, Nevada. Appl. Geol. 17(6), 825$10 \quad 836$.

11 Vanmiddlesworth, L., J. Handle, and P. Johns. 2000. Iodine-129 in thyroid glands: A sensitive 12 biological marker of fission product exposure. J. Radioanal. Nucl. Chem. 243(2), 467-472.

13 Whitehead, D. C. 1973. Studies on iodine in British soils. J. Soil Sci. 24(2), 260-269.

14 Whitehead, D. C. 1974. The sorption of iodine by soil components. J. Sci. Fd. Agric. 25, 73-79.

15 Wolfsberg, K. 1978. Sorption-desorption studies of Nevada Test Site alluvium and leaching 16 studies of nuclear explosion debris. Los Alamos National Laboratory, Los Alamos, NM, 17 LA-7216-MS.

18 Wollum, A. G. I. 1994. Soil sampling for microbiological analysis. Methods of Soil Analysis: 19 Microbiological and Biological Properties. Part 2. pp 1-14 R. W. Weaver, Ed. Madison, 20 Wisconsin, Soil Science Society of American, Inc. 
1 Yamada, H., T. Kiriyama, Y. Onagawa, I. Hisamori, C. Miyazaki, and K. K. Yonebayashi. 1999.

2 Speciation of iodine in soils. Soil Sci. Plant. Nutr. 45(3), 563-568.

3 Yoshida, S., Y. Muramatsu, and S. Uchida. 1992. Studies on the sorption of $\mathrm{I}^{-}$(iodide) and $\mathrm{IO}_{3}{ }^{-}$ 4 onto Andosols. Water, Air Soil Pollu. 63(3-4), 321-329.

5 Yoshida, S., Y. Muramatsu, and S. Uchida. 1998. Soil-solution distribution coefficients, $\mathrm{K}_{\mathrm{d}} \mathrm{S}$, of $6 \quad \mathrm{I}^{-}$and $\mathrm{IO}_{3}^{-}$for 68 Japanese soils. Radiochim. Acta 82, 293-297.

7 Yu, Z., J. A. Warner, R. A. Dahlgren, and W. A. Casey. 1996. Reactivity of iodide in volcanic 8 soils and noncrystalline soil constituents. Geochim. Cosmochim. Acta 60(24), 4945-4956.

9 Yuita, K. 1992. Dynamics of iodine, bromine, and chlorine in soil. Soil Sci. Plant. Nutr. 38(2), $10 \quad 281-287$.

11 Yuita, K. 1994. Overview and dynamics of iodine and bromine in the environment. JARQ, 28, $1290-99$.

13 Zachara, J. M., S. C. Smith, C. X. Liu, J. P. McKinley, R. J. Serne, and P. L. Gassman. 2002. 14 Sorption of $\mathrm{Cs}^{+}$to micaceous subsurface sediments from the Hanford site, USA. Geochim. 15 Cosmochim. Acta 66(2), 193-211. 


\section{Figure Legends}

Figure 1 IC chromatogram for (a) conductivity detection ( $\mu \mathrm{S}$ : microsiemens) of iodate, iodide, and other common inorganic anions, and (b) by amperometric detection for low-level detection of iodide (nC: nanocoulomb).

Figure 2 Breakthrough curves of tritium and iodine species in a column homogeneously packed with Savannah River Site surface soil. The input pulse for tritium, iodide, and iodate is 8.7 column pore volumes and 14.7 pore volumes for 4-iodoaniline. The dashed line is the simulation result for the transport of 4-iodoaniline.

Figure 3 Breakthrough curves for transport of iodate only in SRS surface soil column.

Figure 4 IC chromatograms with amperometric detection for the standard solutions of $1 \times 10^{-5}$ $\mathrm{M}$ iodate or iodide in $5 \times 10^{-6} \mathrm{M} \mathrm{CaCl}_{2}$ to show the nonresponse to iodate at the iodide peak location. We adjusted the position of the baseline in the plotting, but the magnitude of the peak signal response in the y-axis has not been altered.

Figure 5 IC chromatograms with conductivity detection for the (a) SRS surface soil and (b) Hanford sediment samples with three treatments (blank: $5 \times 10^{-6} \mathrm{M} \mathrm{CaCl}_{2}$; iodide: $1 \times 10^{-5} \mathrm{M}$ iodide in $5 \times 10^{-6} \mathrm{M} \mathrm{CaCl}_{2}$; and iodate: $1 \times 10^{-5} \mathrm{M}$ iodate in $5 \times 10^{-6} \mathrm{M}$ $\left.\mathrm{CaCl}_{2}\right)$.

Figure 6 IC chromatograms with conductivity detection for the (a) kaolinite and (b) illite mineral samples with three treatments (blank: $5 \times 10^{-6} \mathrm{M} \mathrm{CaCl}_{2}$; iodide: $1 \times 10^{-5} \mathrm{M}$ iodide in $5 \times 10^{-6} \mathrm{M} \mathrm{CaCl}_{2}$; iodate: $1 \times 10^{-5} \mathrm{M}$ iodate in $5 \times 10^{-6} \mathrm{M} \mathrm{CaCl}_{2}$ ). 
Figure 7 Breakthrough curves for the transport of iodine species in SRS subsoil column. The input pulse for (1) the run of tritium, $10^{-5} \mathrm{M}$ iodide, and iodate is 5.9 , (2) $10^{-4} \mathrm{M}$ iodide and iodate is 7.2, and (3) 4-iodoaniline is 6.1 column pore volumes, respectively.

Figure 8 Breakthrough curves for the transport of iodide and iodate in SRS surface soil column. The input pulses vary among the tests, as indicated by the vertical lines in the graph.

Figure 9 Breakthrough curves for the transport of iodine species in SRS aquifer sample column. The input pulse for (1) the run of tritium, $10^{-5} \mathrm{M}$ iodide, and iodate is 18.8, (2) $10^{-4} \mathrm{M}$ iodide and iodate is 6.3 , and (3) 4-iodoaniline is 14.0 column pore volumes, respectively. Dashed lines are the simulations for the transport of iodate at two initial concentrations.

Figure 10 Breakthrough curves for the transport of iodide and iodate in the column packed with Hanford sediment.

Figure 11 The residence time effect on breakthrough curves for the transport of iodide and iodate in SRS surface soil column. 
Table 1. Information and properties of samples used in this study

\begin{tabular}{|c|c|c|c|c|c|}
\hline Name & Units & $\begin{array}{c}\text { SRS } \\
\text { surface } \\
\text { soil } \\
\end{array}$ & $\begin{array}{c}\text { SRS } \\
\text { subsoil }\end{array}$ & $\begin{array}{l}\text { SRS } \\
\text { aquifer }\end{array}$ & $\begin{array}{l}\text { Hanford } \\
\text { sediment }\end{array}$ \\
\hline Description & & Surface soil & $\begin{array}{l}\text { Composite } \\
\text { of } \\
\text { sediments } \\
\text { collected } \\
\text { over } 3-\mathrm{m} \\
\text { span } 12 \mathrm{~m} \\
\text { below } \\
\text { surface }\end{array}$ & Aquifer & $\begin{array}{l}\text { Composite of } \\
\text { core samples } 9- \\
12 \mathrm{~m} \text { below } \\
\text { surface in the } \mathrm{S} \\
\text { SX tank farm }\end{array}$ \\
\hline Location & & Aiken, SC & Aiken, SC & Aiken, SC & Richland, WA \\
\hline $\mathrm{pH}$ & (1:1) DI water & 4.90 & 5.36 & 5.42 & 8.46 \\
\hline Organic matter & $(\%)$ & 2.3 & 0.072 & 0.013 & 0.060 \\
\hline \multirow{3}{*}{ Particle size } & sand (\%) & 87.6 & 76.7 & 97.2 & 89.0 \\
\hline & silt (\%) & 2.9 & 3.5 & 0.9 & 7.9 \\
\hline & clay $(\%)$ & 9.5 & 19.8 & 1.9 & 3.1 \\
\hline $\begin{array}{l}\text { Cation exchange } \\
\text { capacity }\end{array}$ & $(\mathrm{meq} / 100 \mathrm{~g})$ & 1.3 & 1.8 & 0.064 & 7.4 \\
\hline $\begin{array}{l}\text { Anion exchange } \\
\text { capacity }\end{array}$ & (meq/100 g) & 0.27 & 4.0 & 0.15 & 0.0071 \\
\hline Iron & (oxalate ext.) & 0.32 & 0.20 & 0.036 & 0.94 \\
\hline Iron & (CBD ext.) & 2.5 & 16 & 7.3 & 3.3 \\
\hline Aluminum & (oxalate ext.) & 0.38 & 0.37 & 0.0081 & 0.46 \\
\hline Aluminum & (CBD ext.) & 0.97 & 2.5 & 0.42 & 0.28 \\
\hline Clay mineralogy ${ }^{\mathrm{a}}$ & & $\begin{array}{c}\text { HIV, } \\
\text { kaolinite }\end{array}$ & $\begin{array}{c}\text { kaolinite, } \\
\text { goethite, } \\
\text { HIV }\end{array}$ & $\begin{array}{l}\text { goethite, } \\
\text { kaolinite, I }\end{array}$ & $\begin{array}{l}\text { smectite, } \\
\text { chlorite, mica }\end{array}$ \\
\hline
\end{tabular}

CBD ext. = citrate-bicarbonate-dithionite extraction

oxalate ext. = ammonium oxalate extraction

HIV = hydroxyl interlayered vermiculite

I $\quad=$ illite or weathered mica

${ }^{a}$ Data from Seaman et al. (1996) for SRS samples and Zachara et al. (2002) for Hanford sample. 
Table 2. Mass recovery and sorption parameters from column experiments. ${ }^{\mathrm{a}}$

\begin{tabular}{|c|c|c|c|c|c|c|}
\hline & & $\begin{array}{c}\text { Input } \\
\text { concentration }\end{array}$ & $\begin{array}{l}\text { Mass } \\
\text { recovery }\end{array}$ & $R_{f}$ & $k_{2}(1 / \mathrm{h})$ & $F$ \\
\hline \multirow{6}{*}{$\begin{array}{c}\text { SRS } \\
\text { surface } \\
\text { soil }\end{array}$} & Tritium & $30 \mathrm{kBq} / \mathrm{L}$ & 1.00 & 0.95 & & \\
\hline & Iodide & $1 \times 10^{-5} \mathrm{M}$ & 0.94 & 0.93 & & \\
\hline & Iodide & $1 \times 10^{-4} \mathrm{M}$ & 0.66 & 0.99 & & \\
\hline & Iodate & $1 \times 10^{-5} \mathrm{M}$ & 0.83 & 2.92 & & \\
\hline & Iodate & $1 \times 10^{-4} \mathrm{M}$ & 0.97 & 2.29 & & \\
\hline & 4-iodoaniline & $4 \times 10^{-5} \mathrm{M}$ & 0.53 & 25.9 & 0.027 & 0.82 \\
\hline \multirow{6}{*}{$\begin{array}{c}\text { SRS } \\
\text { subsoil }\end{array}$} & Tritium & $30 \mathrm{kBq} / \mathrm{L}$ & 0.99 & 1.06 & & \\
\hline & Iodide & $1 \times 10^{-5} \mathrm{M}$ & 0.56 & 5.50 & & \\
\hline & Iodide & $1 \times 10^{-4} \mathrm{M}$ & 1.03 & 6.30 & & \\
\hline & Iodate & $1 \times 10^{-5} \mathrm{M}$ & 0.00 & $\mathrm{NA}^{\mathrm{b}}$ & & \\
\hline & Iodate & $1 \times 10^{-4} \mathrm{M}$ & 0.00 & $\mathrm{NA}^{\mathrm{b}}$ & & \\
\hline & 4-iodoaniline & $1 \times 10^{-5} \mathrm{M}$ & 1.12 & 0.97 & & \\
\hline \multirow{6}{*}{$\begin{array}{c}\text { SRS } \\
\text { aquifer }\end{array}$} & Tritium & $30 \mathrm{kBq} / \mathrm{L}$ & 0.99 & 1.00 & & \\
\hline & Iodide & $1 \times 10^{-5} \mathrm{M}$ & 1.00 & 1.35 & & \\
\hline & Iodide & $1 \times 10^{-4} \mathrm{M}$ & 0.95 & 1.31 & & \\
\hline & Iodate & $1 \times 10^{-5} \mathrm{M}$ & $>0.80^{\mathrm{c}}$ & 16.2 & 0.23 & 0.22 \\
\hline & Iodate & $1 \times 10^{-4} \mathrm{M}$ & $>0.72^{\mathrm{c}}$ & 7.92 & 0.49 & 0.22 \\
\hline & 4-iodoaniline & $1 \times 10^{-5} \mathrm{M}$ & 1.04 & 0.90 & & \\
\hline \multirow{5}{*}{$\begin{array}{l}\text { Hanford } \\
\text { sediment }\end{array}$} & Tritium & $30 \mathrm{kBq} / \mathrm{L}$ & 0.95 & 1.14 & & \\
\hline & Iodide & $1 \times 10^{-5} \mathrm{M}$ & 1.00 & 1.33 & & \\
\hline & Iodide & $1 \times 10^{-4} \mathrm{M}$ & 1.01 & 1.05 & & \\
\hline & Iodate & $1 \times 10^{-5} \mathrm{M}$ & 0.99 & 1.93 & & \\
\hline & Iodate & $1 \times 10^{-4} \mathrm{M}$ & 1.06 & 1.41 & & \\
\hline
\end{tabular}

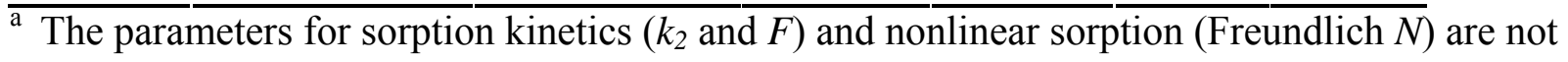
available for the breakthrough curves that can be described by linear equilibrium assumption (e.g., with minimal sorption) and that have apparent irreversible retention or conversion of iodine species (e.g., in SRS subsoil). 
${ }^{\mathrm{b}} \mathrm{NA}$ : not available because there is no breakthrough for iodate in the experimental conditions.

${ }^{c}$ Incomplete recovery because of limited experimental duration.

Table 3. Reduction capacity of

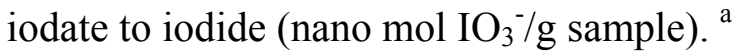

\begin{tabular}{cc}
\hline SRS surface soil & $0.80 \pm 0.31$ \\
SRS subsoil & $0.16 \pm 0.022$ \\
SRS aquifer & $1.2 \pm 0.38$ \\
Hanford sediment & $5.2 \pm 0.48$ \\
Kaolinite & $9.4 \pm 1.4$ \\
Illite & $14 \pm 0.69$ \\
Montomorillonite & $18 \pm 1.5$ \\
Vermiculite & 0 \\
\hline
\end{tabular}

${ }^{a}$ Average \pm standard deviation for three replicates. 
Figure 1

(a)

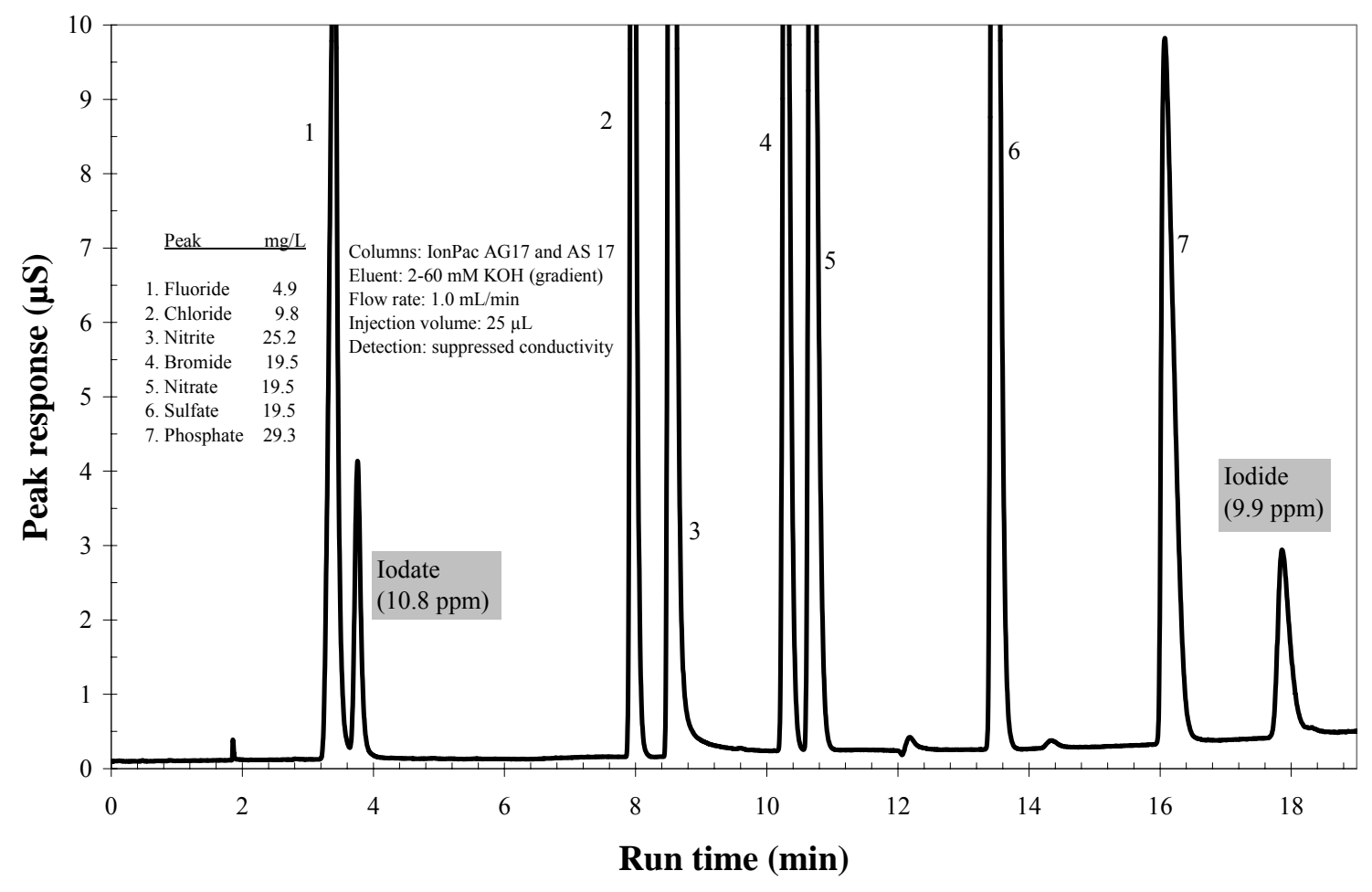

(b)

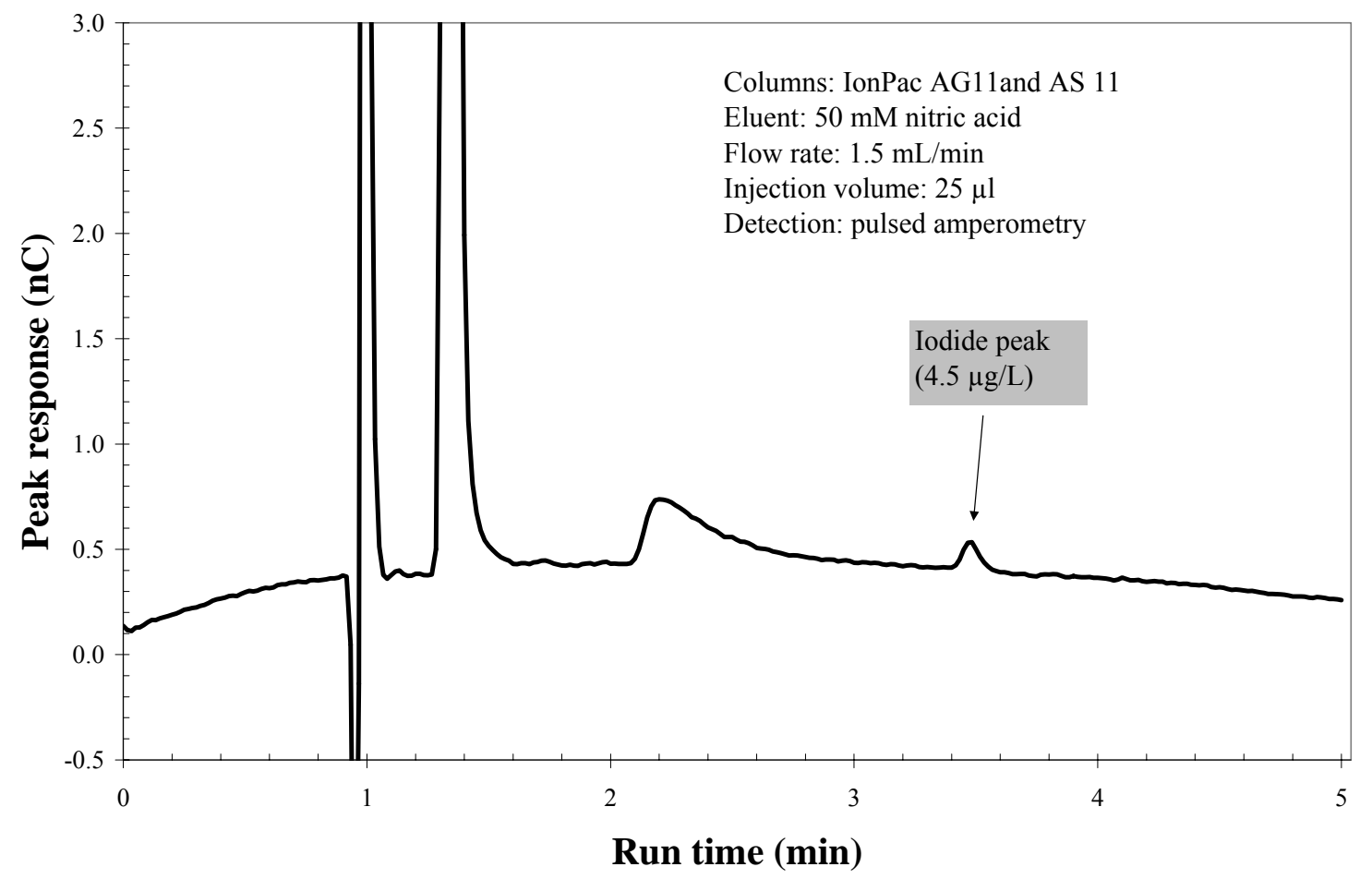


Figure 2

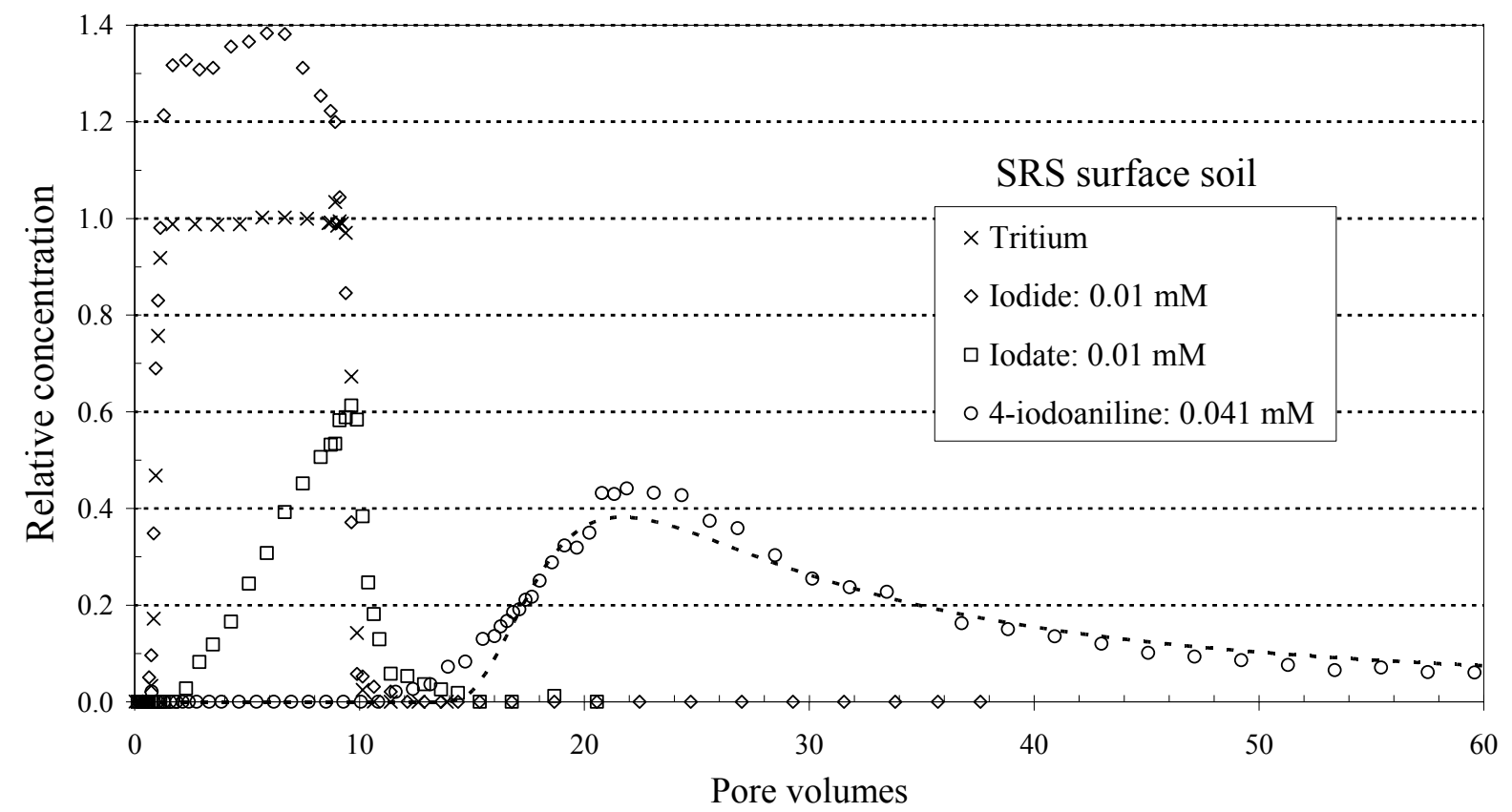


Figure 3

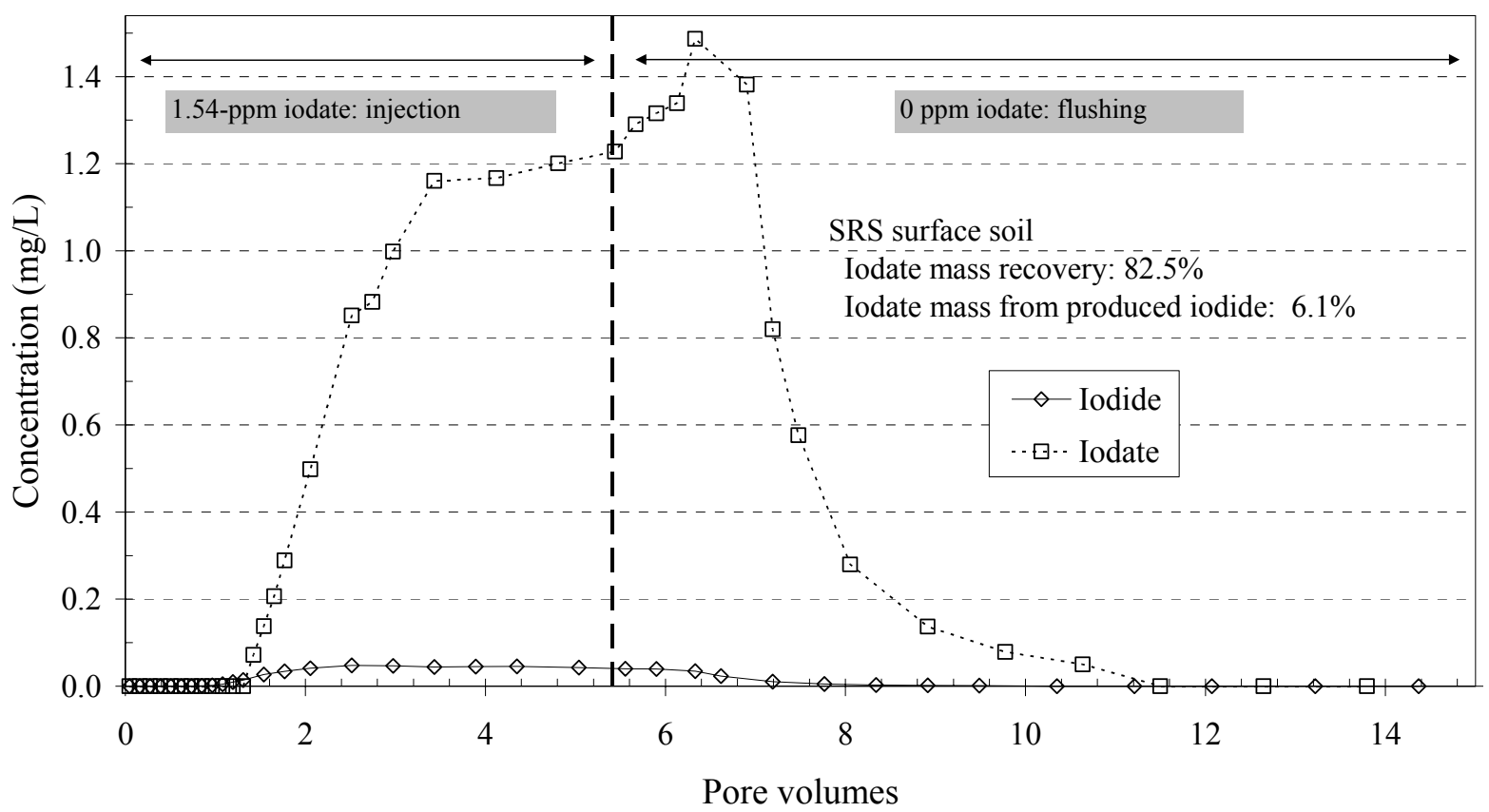


Figure 4

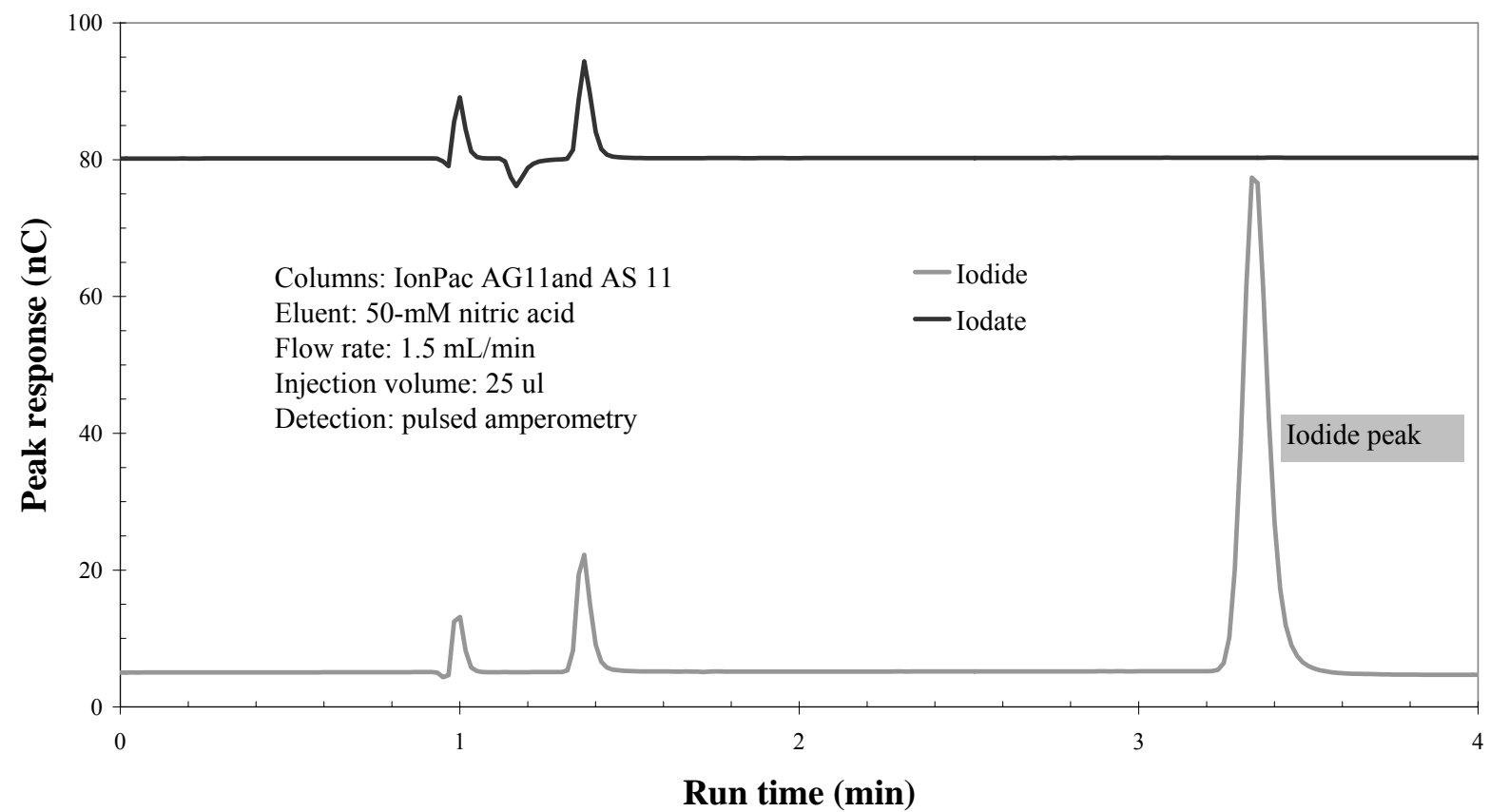


Figure 5

(a)

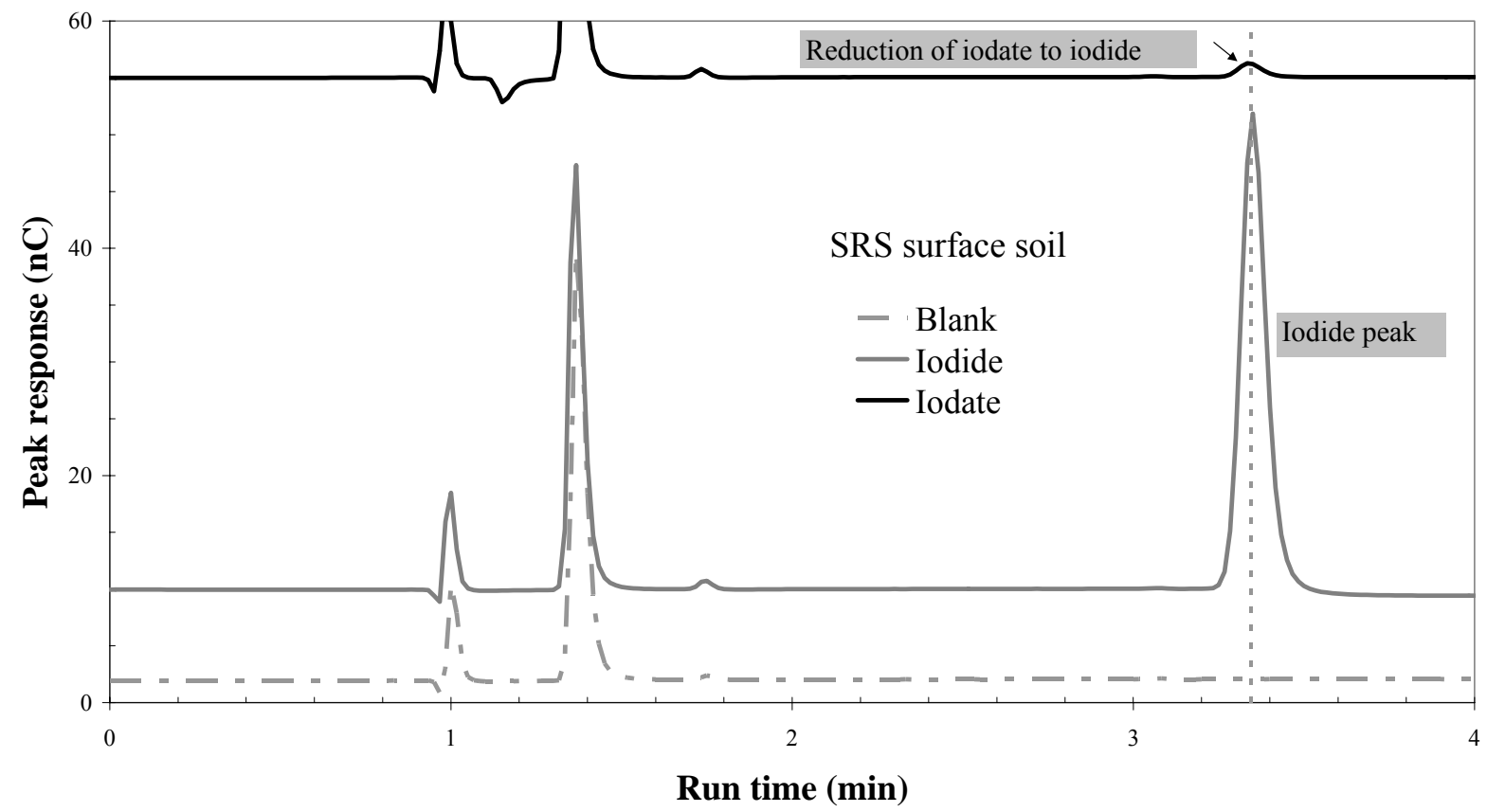

(b)

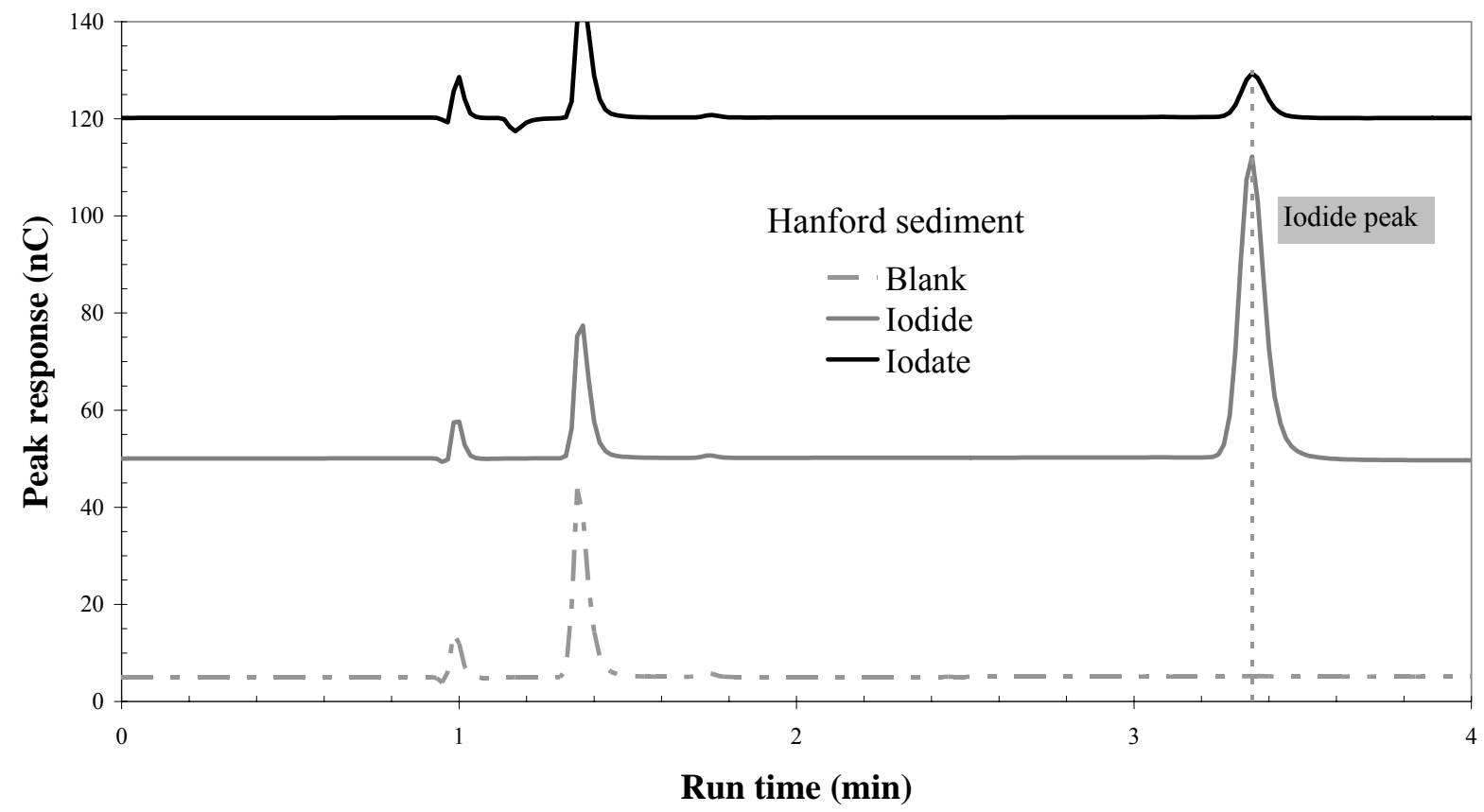


Figure 6

(a)

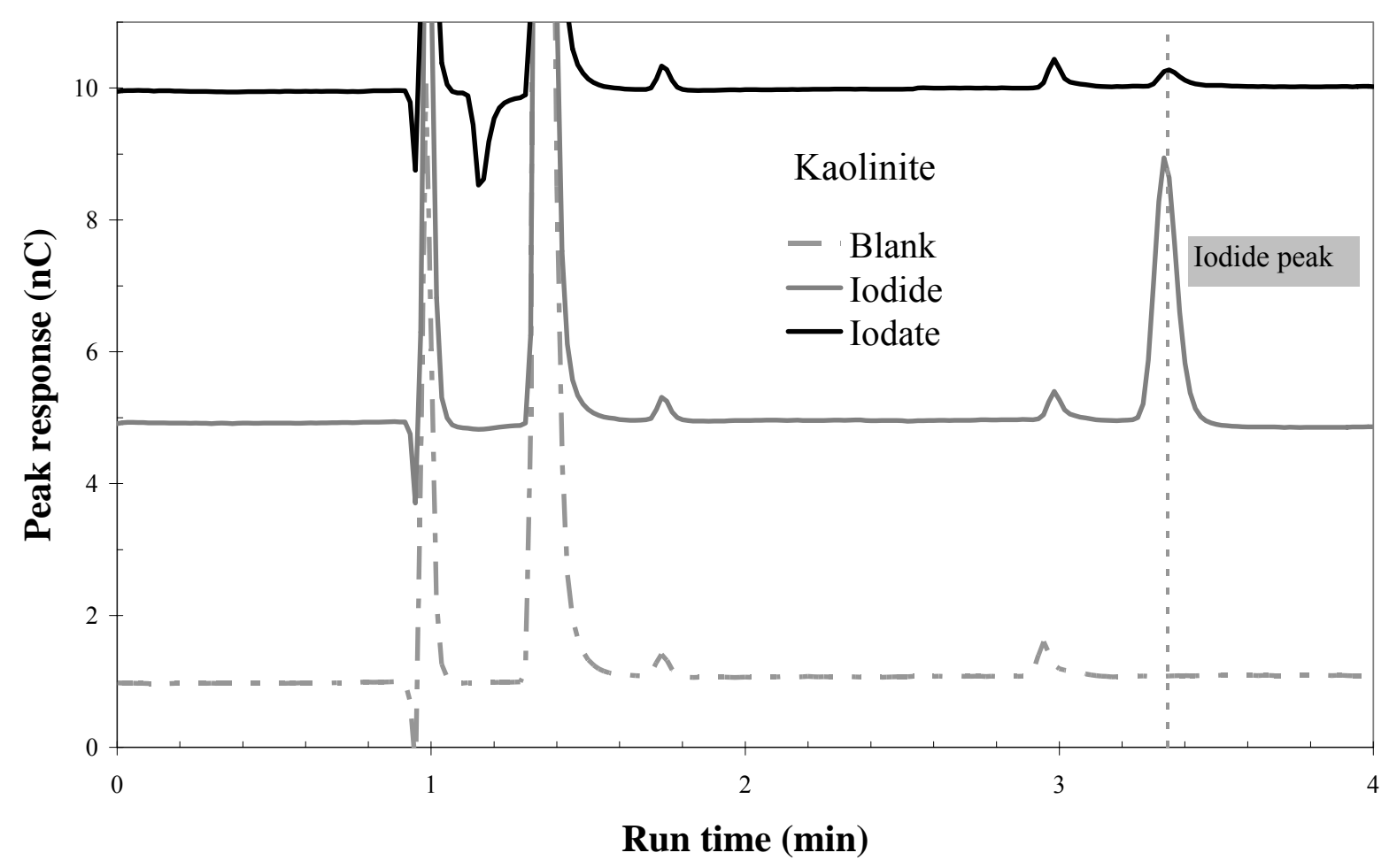

(b)

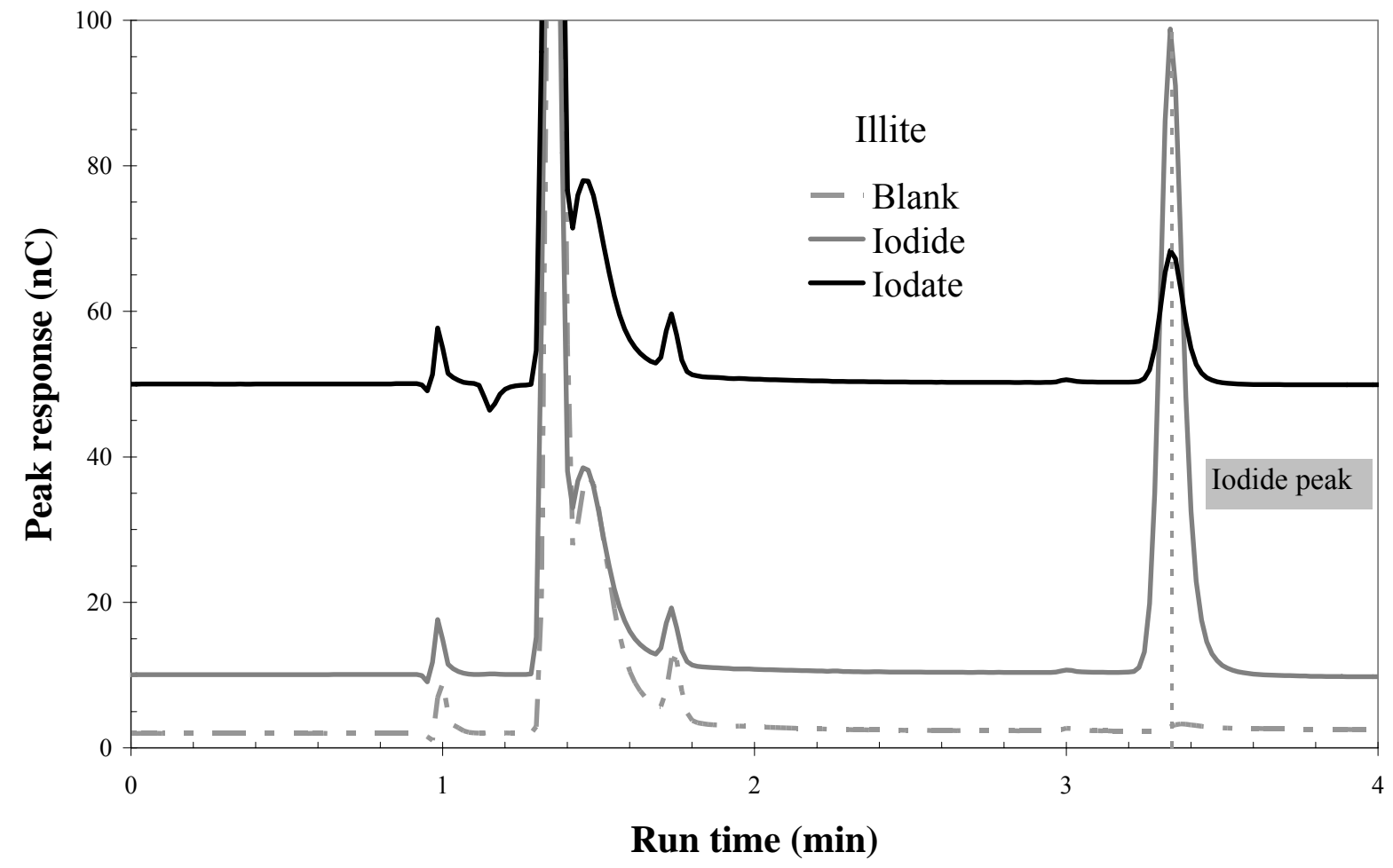


Figure 7

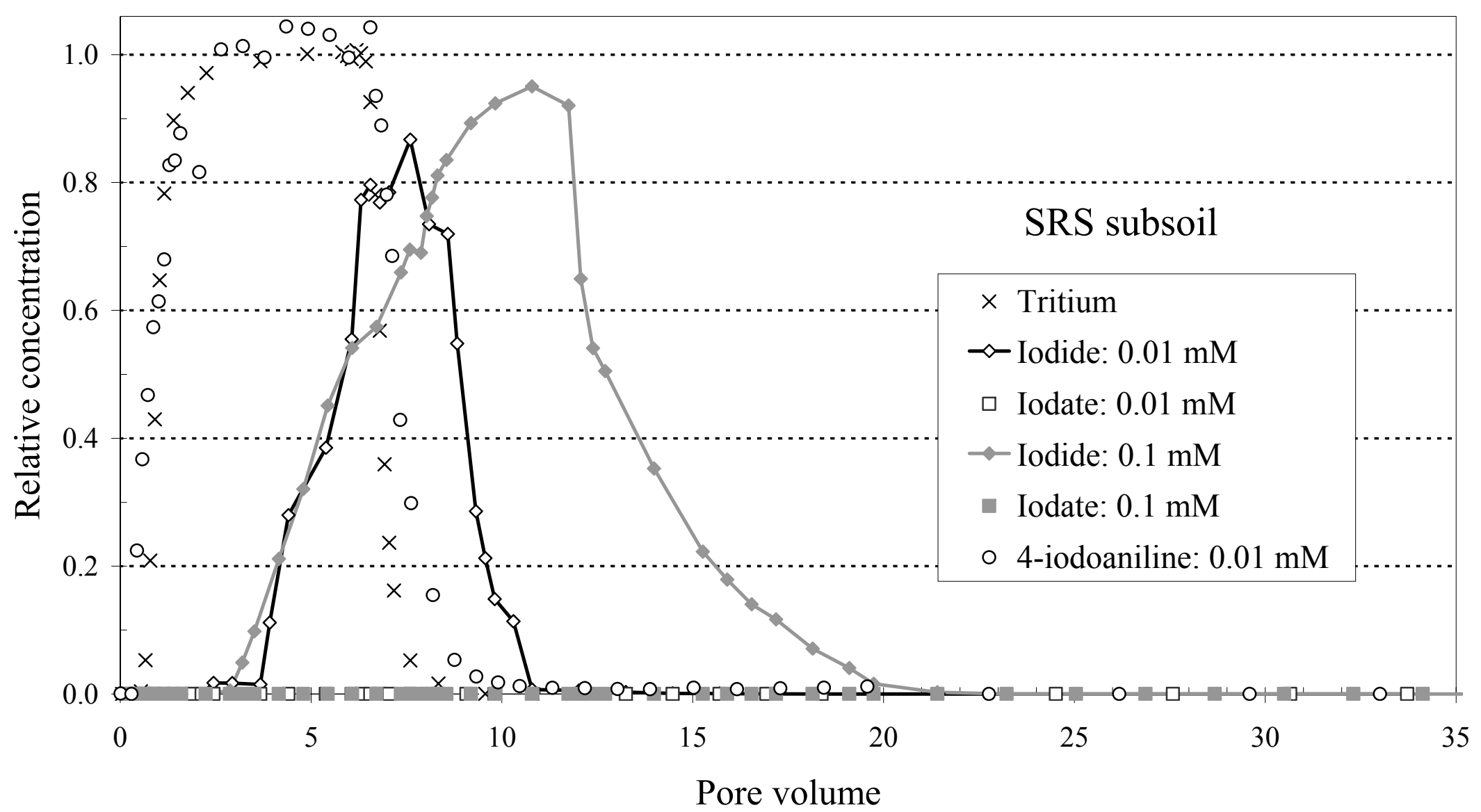


Figure 8

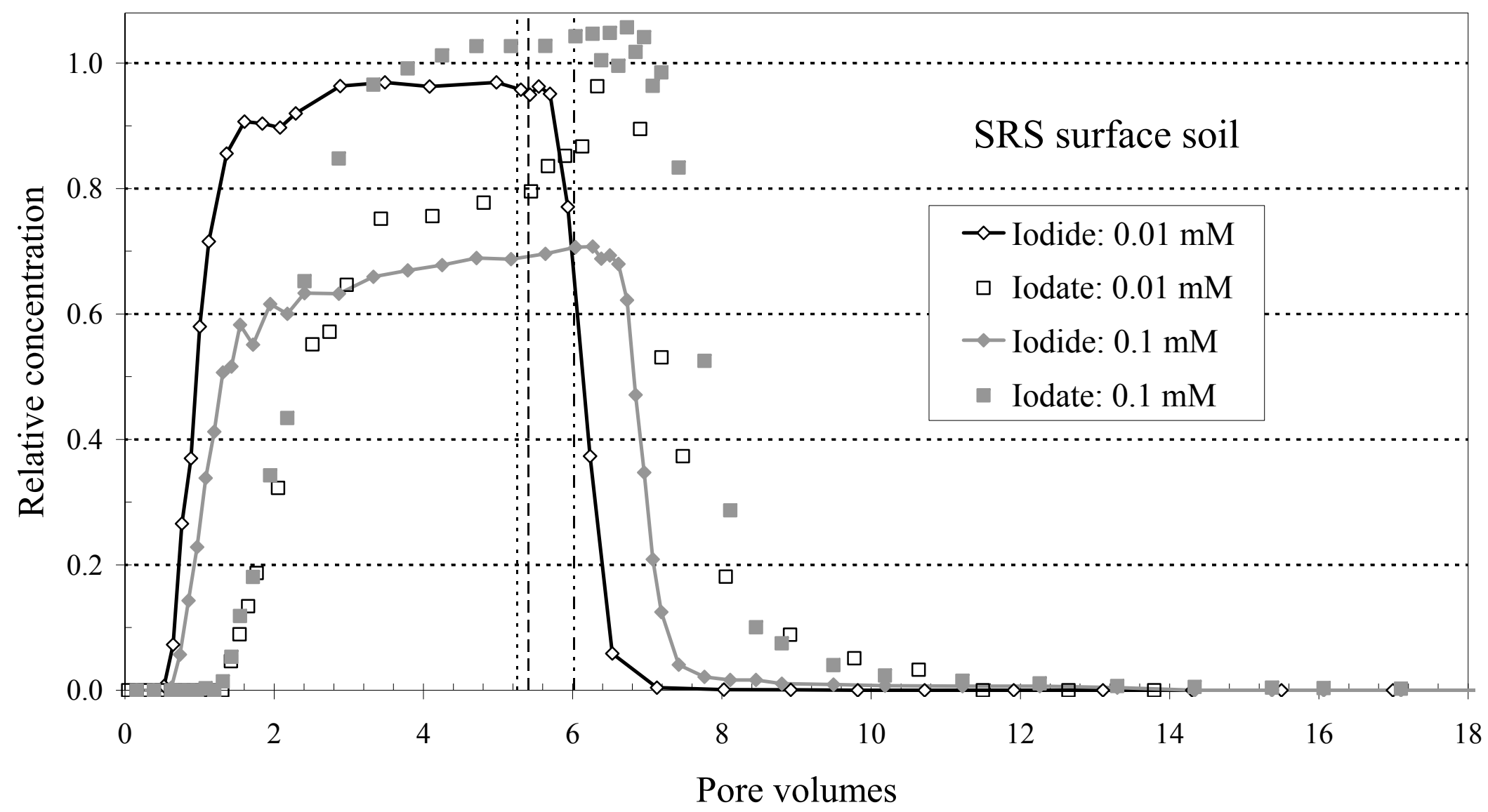


Figure 9

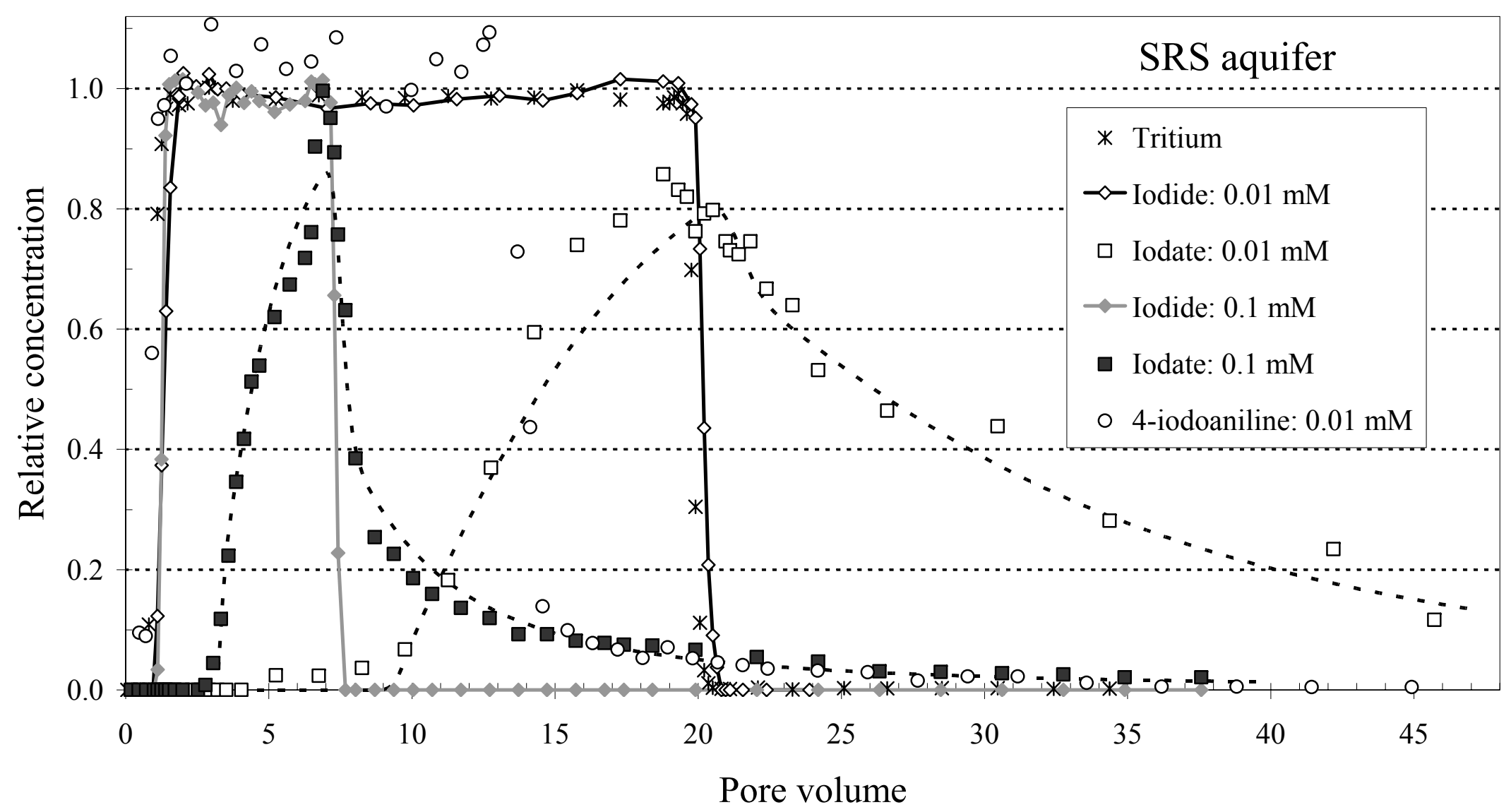


Figure 10

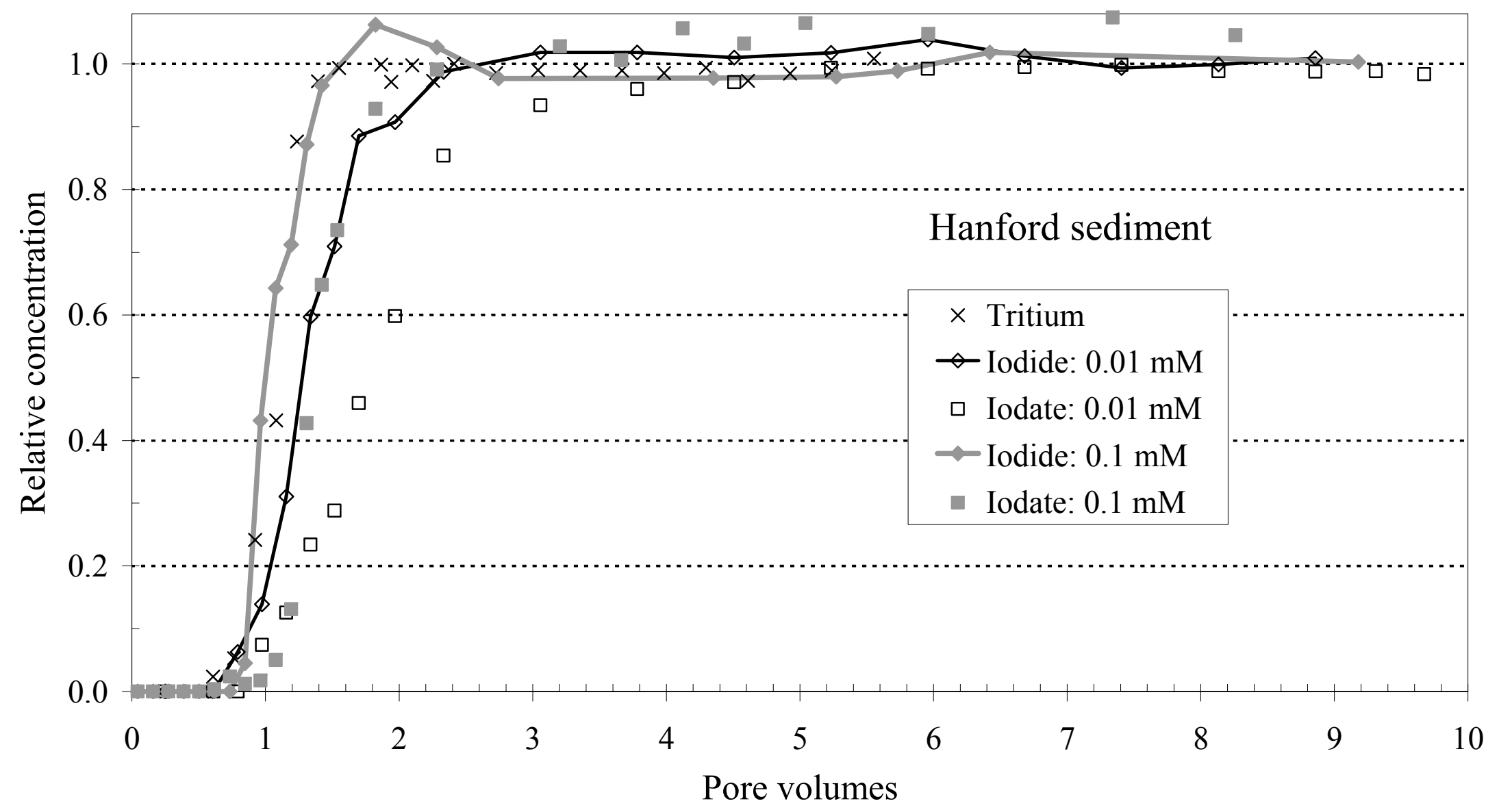


Figure 11

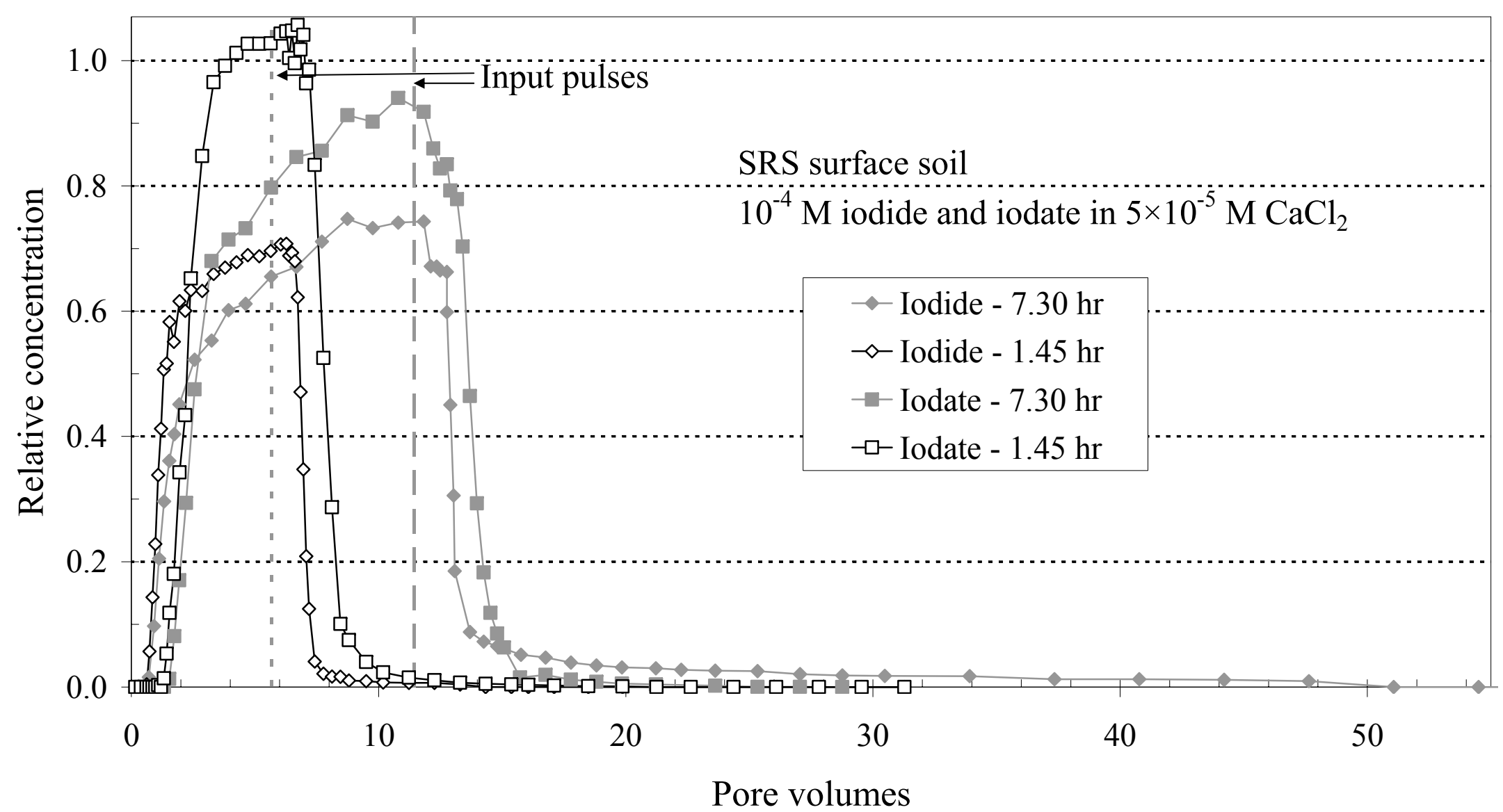

